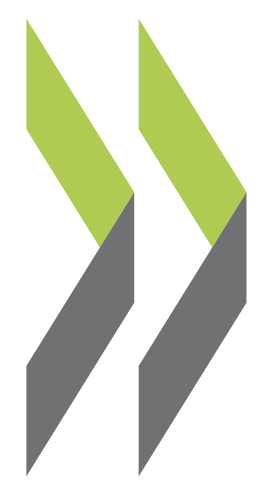

OECD Economics Department Working Papers No. 311

\author{
Modelling Import \\ Responsiveness for OECD \\ Manufactures Trade
}

Mara Meacci, David Turner 
Organisation de Coopération et de Développement Economiques

Organisation for Economic Co-operation and Development

ECONOMICS DEPARTMENT

English text only

MODELLING IMPORT RESPONSIVENESS FOR OECD MANUFACTURES TRADE

ECONOMICS DEPARTMENT WORKING PAPERS NO. 311

by

Mara Meacci and David Turner

Almost all Economics Department Working Papers are now available through OECD's Internet Web site at http://www.oecd.org/eco 


\section{ABSTRACT/RÉSUMÉ}

\section{MODELLING IMPORT RESPONSIVENESS FOR OECD MANUFACTURES TRADE}

The degree of integration and openness of OECD economies has consistently increased throughout most of the past three decades. By limiting the influence of non-economic factors, and reducing heterogeneity in economic systems, increased integration and openness enhance the emergence of common patterns of adjustment to economic shocks among countries. This paper focuses on the demand and price elasticity of manufacturing import volumes in OECD countries, examining if the long-run adjustment of the volume of manufacturing imports to demand and price shocks is similar across countries. The results indicate that the percentage long-run adjustment of manufacturing import volumes to a demand shock is similar across the majority of OECD countries. The adjustment of manufacturing import volumes to relative price shocks are more heterogeneous, although it is possible to identify clusters of countries showing similar responses. The estimated short and long-run demand elasticities are typically considerably greater than one, and shocks to domestic demand generally cause overshooting of manufacturing import volumes. Long and short-run price elasticities are generally dispersed around values lower than one, with $80 \%$ of the full adjustment of manufacturing import volumes to relative price shocks completed in under two years.

JEL: $\mathrm{C} 20, \mathrm{C} 22, \mathrm{~F} 17, \mathrm{~F} 47$

Keywords: IMPORTS, ELASTICITIES, FORECASTING and SIMULATION

\section{MODÉLISER LA RÉACTION DES IMPORTATIONS DANS LE COMMERCE MANUFACTURIER DES PAYS DE L'OCDE}

L'intégration et l'ouverture des économies de l'OCDE se sont régulièrement accrues au cours des trois dernières decennies. En limitant l'influence des facteurs non économiques et en réduisant l'hétérogénéité des systèmes économiques, une intégration et une ouverture plus importantes accentuent la similarité entre les pays dans leurs ajustements aux chocs économiques. Cet article estime les élasticites prix et demande des volumes d'importation de biens manufacturiers dans les pays de l'OCDE et analyse la similarité entre pays de l'ajustement des importations de biens manufacturiers à des chocs de demande et de prix. Les résultats obtenus montrent que l'ajustement de long terme des volumes d'importations manufacturières à un choc de demande est de même ampleur dans la majorité des pays de l'OCDE. Les ajustements des volumes d'importations manufacturieres à des chocs de prix relatifs sont plus hétérogènes, même s'il est possible d'identifier des groupes de pays présentant des réponses similaires. Les estimations des élasticités de court et long terme de demande sont de manière générale très supérieures à l'unité. Par ailleurs, les chocs de demande intérieure provoquent généralement un sur-ajustement des volumes d'importation manufacturières. Les élasticites de court et long terme des prix varient la plupart du temps autour de valeurs inférieures à un, $80 \%$ de l'ajustement total des importations manufacturières aux chocs de prix relatifs étant réalises avant deux ans.

Classification JEL: C20, C22, F17, F47

Mots-clés: IMPORTATIONS, ELASTICITES, PREVISION et SIMULATION

\section{Copyright: OECD, 2001}

Applications for permission to reproduce or translate all, or part of, this material should be made to: Head of Publications Service, OECD, 2 rue André-Pascal, 75775 PARIS CEDEX 16, France 


\section{TABLE OF CONTENTS}

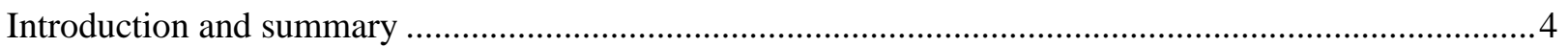

Specification of manufacturing import volumes equations.................................................................... 6

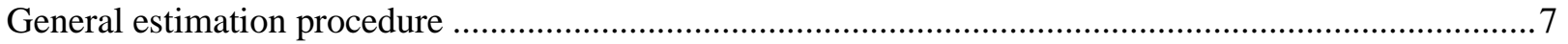

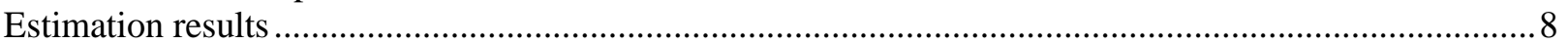

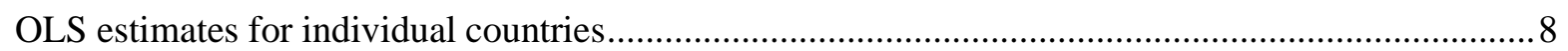

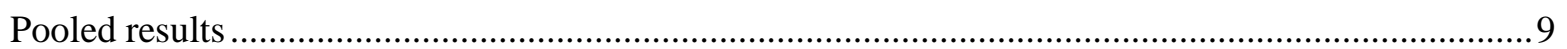

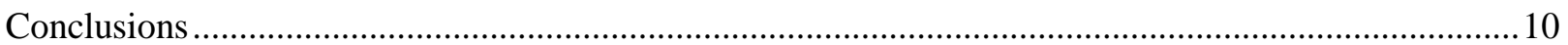

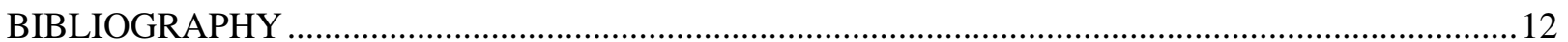

Figures:

1. World output growth and world merchandise trade growth (five-year averages) ...........................13

2. World manufacturing trade as a share of world merchandise trade ...............................................13

3. Manufacturing imports as a percentage of GDP, G-7 countries................................................. 14

4. Single country estimates of long-run demand and price elasticities, deviations

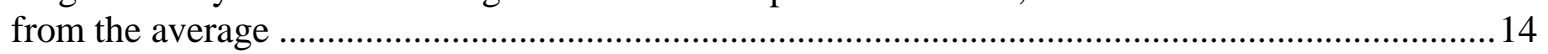

5. The response of manufacturing import volumes to one percentage point increase in final

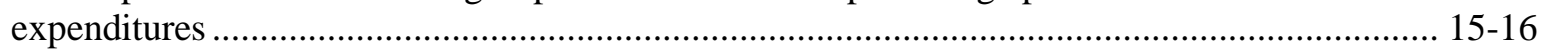

6. The response of manufacturing import volumes to one percentage point increase in

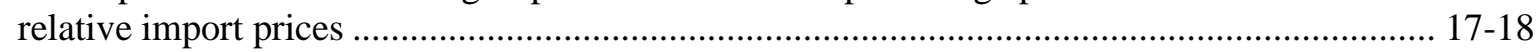

Tables:

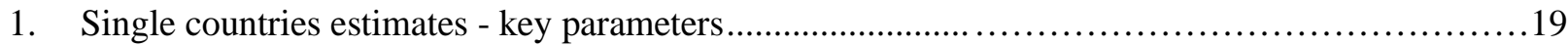

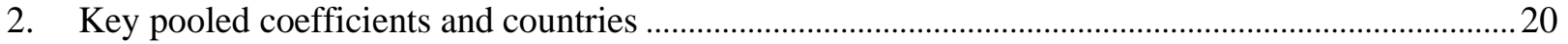

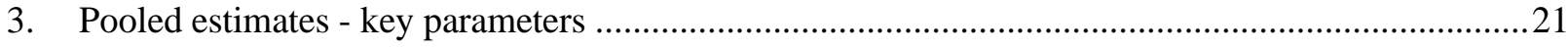

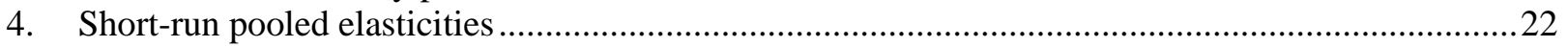

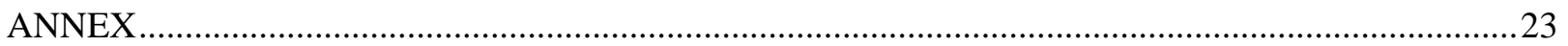

Annex figures

1.1 Ratio of manufacturing imports to total expenditures in volumes, Germany.

Annex tables:

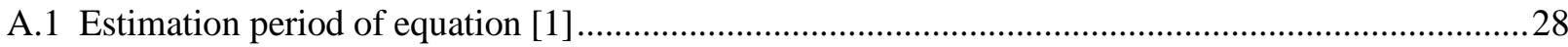

A.2 Detailed estimation results of equation [1], pooled coefficients ............................................... 29-31

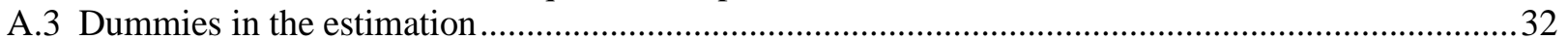




\title{
MODELLING IMPORT RESPONSIVENESS FOR OECD MANUFACTURES TRADE
}

\author{
by Mara Meacci and David Turner ${ }^{1}$
}

\section{Introduction and summary}

1. The degree of integration and openness of OECD economies has increased consistently throughout most of the past three decades. Growth in world trade ${ }^{2}$ has constantly outstripped that of world output, with the difference between the average rate of growth of world merchandise trade to that of world output rising steadily from just under 2 per cent in the period from 1976 to 1980 , to around 4 per cent in the late 1990s (Figure 1) ${ }^{3}$. Trade in manufactured goods has dominated these trends, with the share of world trade in manufactured goods over world trade of total goods rising steadily from 66 per cent in 1975 to 82 per cent in 1999 (Figure 2).

2. Associated with these trends there has been a substantial rise in import penetration across all OECD countries, particularly in manufacturing goods ${ }^{4}$. Among the major seven OECD economies manufacturing imports as a percentage of GDP have risen markedly (Figure 3): for the largest four European countries manufacturing imports as a percentage of GDP moved from an average of 8.4 per cent in 1970 to 16 per cent in 1999. In the United States they moved from 2.7 per cent in 1970 to 9.7 per cent in 1999. Canada is the G7 country showing the maximum increase of manufacturing imports as a percentage of GDP, rising from 11.5 per cent in 1970 to 27.6 per cent in 1999. The acceleration in Canadian import penetration is especially substantial in the period 1992-99, as a consequence of the various stages of implementation of the Free Trade Agreement. Japan is the G7 country with the most modest increase in manufacturing import penetration: manufacturing imports as a percentage of GDP grew from 2.6 per cent to only 3.9 per cent between 1970 and 1999. Although this increase is modest, it should be judged in the context of a fall in total imports of goods and services as a percentage of GDP by 6 percentage points 5 .

1. The authors are members of the Macroeconomic Analysis and Systems Management Division of the Economics Department. The opinions expressed in this paper are those of the authors and do not necessarily represent those of the OECD or of its Member countries. Special thanks go to Pete Richardson and Claude Giorno for their useful comments and suggestions at various stages of the work; to Laurence Le Fouler and Isabelle Wanner-Paoletti for their excellent statistical assistance; and also for the sterling work of Rosemary Chahed and Jan-Cathryn Davies in document preparation. The responsibility for all errors and omissions rests with the authors.

2. To which OECD countries contribute around 70 per cent.

3. With the exception of the slowdown during the period 1981-1985 in which the ratio of world trade merchandise growth to world output went down to 0.2 per cent.

4. Export penetration has followed a broadly similar pattern of growth.

5. The most substantial downturn in import penetration for Japan is in 1985-1986, following a strong decline of oil imports. Cfr. OECD 1986 for more details. 
3. By limiting the influence of non-economic factors, and reducing heterogeneity in economic systems, greater openness and integration of markets increase the likelihood of common responses of import volumes to economic shocks. Given the increased importance of manufacturing trade in relation to GDP, and its overall weight in imports ${ }^{6}$, manufacturing imports play an increasingly important role in macroeconomic adjustment ${ }^{7}$.

4. This paper examines these issues in the context of estimated demand and price elasticities of manufacturing import volumes across OECD countries, analysing in particular if the hypothesis of common patterns of adjustment to demand and relative price shocks is accepted or not. A pooled estimation approach, allowing common parameters to be identified and imposed ${ }^{8}$ across countries, is used. This approach has a number of attractions relating both to the specific estimation of import equations and to more general modelling considerations.

5. Firstly, the relative size of demand and price elasticities of manufacturing import volumes has important implications for the impact of shocks across OECD countries. According to the estimates presented here, an adverse area-wide demand shock of one percentage point would cause a decline of OECD manufacturing import volumes of 1.8 percentage points ${ }^{9}$, and a negative shock of one percentage point to relative import prices would increase manufacturing import volumes by 0.8 percentage points.

6. Secondly, from a modelling point of view, common parameters have the advantage of allowing for more robust and parsimonious econometric representations. Country-specific responses are allowed to deviate from group averages only when there is strong evidence in support of it. A pooled estimation approach also provides criteria to deal with situations where country specific coefficients are unobtainable or implausible. With respect to other pooled estimation methods ${ }^{10}$, the method adopted here has the desirable property of reducing induced aggregation biases on short-run coefficients, and thus provides more reliable estimates of short-run dynamics. The hypothesis of common long-run equilibrium across countries is not assumed but tested on a "coefficient by coefficient" basis. Each long-run coefficient may thus be pooled to its closest single country value, and it is allowed the possibility of pooling long-run demand and price elasticities to different clusters.

7. The results support the hypothesis of common long-run responses across OECD countries of manufacturing import volumes to demand shocks. In particular, for the majority of OECD countries the long-run adjustment of manufacturing import volumes is about one and a half time the magnitude of the demand shock. Impact demand elasticities are more dispersed and generally higher than long-run demand elasticities, so that manufacturing import volumes tend to overshoot in response to a demand shock. The hypothesis of common responses across OECD countries of manufacturing import volumes to relative price shocks is instead rejected by the data, although it is possible to identify clusters of countries sharing the same impact and long-run price elasticities. The clusters are, however, more numerous and the clustering centres more dispersed than those for demand elasticities. The long-run adjustment of manufacturing import volumes to relative price shocks ranges from a minimum of one-third to a maximum

6. In 1999 the average share for G7 countries of manufacturing imports over total imports has been 63 per cent.

7. This is despite the fact that manufacturing production as a share of GDP has declined in most of the largest OECD economies. For the US, for example, it has moved from 21.5 per cent in 1980 to 17.6 per cent in 1997; and for Japan from 29.2 per cent in 1980 to 25.2 in 1997.

8. When the restrictions are accepted by the data.

9. Based on a ceteris paribus assumption. OECD area effects are GDP-weighted averages of single country effects.

10. Cfr., for example, the Pool Mean Group Estimator proposed by Pesaran, Shin, and Smith (1999). 
of $1 \frac{1 / 4}{4}$ times the magnitude of the price shock. Impact price elasticities are normally lower than long-run price elasticities: the adjustment of manufacturing import volumes following price shocks is thus fairly gradual. The adjustment of manufacturing import volumes to relative price shocks is quick: for the majority of countries less than one year is required to complete 80 per cent of the adjustment.

8. The rest of the paper is organised as follows. In Section 1, the specification used to estimate demand and price elasticities of manufacturing import volumes is presented and discussed. Section 2 describes the general estimation procedure. The estimation results are presented in Section 3. A summary of the results obtained concludes the paper.

\section{Specification of manufacturing import volumes equations}

9. The structure of the equations has been kept parsimonious to ensure its applicability to the greater possible number of countries. For each country, the volume of the demand for manufacturing imports is modelled as a positive function of the volume of total expenditures, and a negative function of relative import prices. Relative import prices are measured as the ratio between the unit value of manufactured goods imports and the total final expenditure deflator. The equations have an error correction specification that distinguishes between long and short-run dynamic adjustment. The coefficient on the error correction term, and the short-run lag structure, determine the length of the process of adjustment to equilibrium. The general form of the estimated import volume equations is:

$$
\begin{aligned}
& \Delta \ln M M V_{t}=\alpha_{0}+\beta_{j_{1}} \Delta \ln M M V_{t-j 1}+\beta_{j 2} \Delta \ln T E V X_{t-j 2}+\gamma_{j 3} \Delta \ln R P M_{t-j 3} \\
& +\delta_{1}\left(\ln M M V_{t-1}-\delta_{2} \ln T E V X_{t-1}-\delta_{3} \ln R P M_{t-1}\right)
\end{aligned}
$$

where $\mathrm{j}_{1}=1, . ., 3 \quad \mathrm{j}_{2}=0, . ., 3 \quad \mathrm{j}_{3}=0,1$ Variables definitions ${ }^{11}$ are as follows:

MMV = manufactured goods imports, volume, customs basis

TEVX = Total expenditure excluded government wage consumption, volume

$\mathrm{PMM}=$ Manufactured goods imports, unit value, customs basis

$\mathrm{PTE}=$ Total expenditure excluded government wage consumption, deflator

$\mathrm{RPM}=(\mathrm{PMM} / \mathrm{PTE})$

The form of equation [1] ${ }^{12}$ allows direct estimates of the error correction term coefficient, $\delta_{1}$, of the longrun demand elasticity, $\delta_{2}$, and of the long-run price elasticity, $\delta_{3}$.

10. Before choosing this specification, various attempts were made to include other possibly relevant variables. It is in fact sometimes argued that supply constraints and profitability conditions might bias the response of manufacturing import volumes to changes in demand or relative prices. Also, the various components of total final expenditures might have different import contents depending on the productive and trade structure of the country analysed. This assumption is used, for example, in the IMF model MULTIMOD Mark III (1998) when defining a measure of aggregate activity ${ }^{13}$. Finally, representations describing the long-run evolution of manufacturing imports in terms of a linear trend and unit demand elasticity are often proposed as theoretically and empirically appealing.

11. All data come from the OECD Analytical Database.

12. The specification presented here is similar to the one used in the IMF model Multimod III. Cfr. Laxton et al. (1998) for details.

13. Cfr. Laxton et al. (1998). 
11. Tests were carried out for the inclusion of each of these variables. The ratio of actual to potential GDP relative to the one of the trading partners was used as a proxi for supply constraints in each country. Profitability in each country was proxied by a (broad) measure of mark-up ${ }^{14}$ relative to the one of the trading partners. Tests on G7 countries showed that neither of these variables improved the specification.

12. To determine if the import propensities of the various expenditure components were significantly different, the ratios of, respectively, government final consumption, private fixed capital formation, and exports of goods and services to final expenditures were added to the specification of equation [1] and tested for a possible significant effect. The answer was again negative for G7 countries; and for non-G7 countries only in three cases (Hungary, Mexico and Spain) empirical evidence supported a specification with different import propensities.

13. Finally, a trend representation in terms of non-unit long-run demand elasticity against the inclusion of a linear time trend was tested, and the non-unit demand elasticity representation was preferred for a clear majority of countries.

\section{General estimation procedure}

14. The estimation procedure adopted to test the hypothesis of common demand and price elasticities of manufacturing import volumes across OECD countries involves two stages. In the first one, equation [1] is estimated on a country-by-country basis with OLS and subjected to a range of standard diagnostic tests $^{15}$. In the second, the data are pooled by beginning to test the restriction of a common value for the long-run demand elasticity of the two countries nearest to the average ${ }^{16}$. If accepted, the restriction is imposed, and the next country equation with elasticity nearest to the average long-run elasticity is tested. This procedure is used sequentially among coefficients in the following $\operatorname{order}^{17}$ : long-run demand elasticity, long-run price elasticity, error correction term, short-run coefficients. The reason for this ordering is that the long-run demand elasticity is the parameter that was found to be less dispersed and best determined. The pooled results were obtained estimating the system with OLS ${ }^{18}$.

15. The pooling procedure adopted allows to test sequentially the hypothesis of common parameters across countries and to impose it as a restriction only if supported by the data. More generally, it is a useful procedure to reduce the number of different parameters in a model, increasing at the same time their

14. More precisely, profitability in country $\mathrm{H}$ was defined as the ratio of the total expenditure deflator to unit labour costs in manufacturing. Relative profitability in country $\mathrm{H}$ is the ratio between country $\mathrm{H}$ profitability and the weighted average (with weights computed on the basis of the 1994 matrix of bilateral trade for manufacturing products between countries) of profitabilities of trading partners.

15. Breusch-Godfrey test for up to second order serial correlation; Chow breakpoint test for structural stability of the coefficients breaking the sample period in half; Chow forecast tests of predictive power over the period since the latest three years of estimation; Jarque-Bera test for normality of residuals; Ramsey RESET test for functional form testing the significance of higher powers of fitted values in regression.

16. Using a Wald test for coefficients restrictions.

17. Note that the constant terms in the system are always country-specific.

18. A Breusch-Pagan test was used to detect any evidence of cross-correlation among residuals (in which case SURE estimation would have been appropriate) and the answer was negative. This conclusion is also supported by inspection of the correlation matrix of the residuals that shows quite low cross-correlation values. 
robustness ${ }^{19}$. It also reduces the frequency of implementing parameter revisions ${ }^{20}$ and provides criteria to deal with situations where country specific coefficients are unobtainable or implausible. In these cases, in fact, the pooled coefficients may be imposed as the average value shared by a certain group of countries.

16. The pooling procedure adopted also has the desirable property of attenuating induced aggregation biases on short-run coefficients. By allowing each long-run coefficient to be pooled to its closest single country value, and each country to be assigned to different clusters for demand and price elasticity, shortrun coefficients are maintained as close as possible to their single country estimated values. Other pooling procedures either assume that long and short-run coefficients are common (Fixed Effects Estimator), or long-run coefficients only are assumed to be common but clustered in the same group. This is the case of the Pool Mean Group Estimator proposed by Pesaran et al. (1999), that allows having various clusters for long-run coefficients, but each country (unit) has to participate in only one cluster. The deviations of the long-run coefficients from the clustering centre get reflected in short-run coefficients, whose estimates can be subject to consistent aggregation biases if the hypothesis of communality of long-run coefficients is not strictly supported by the data. While in some frameworks short-run dynamics may be of no special interest, they are particularly important in simulation and forecasting models such as Interlink.

\section{Estimation results}

\section{OLS estimates for individual countries}

17. Equation [1] was estimated for all OECD countries ${ }^{21}$ except Poland, Hungary and Czech Republic, for which the time span of data available is insufficient. Due to the effects of re-unification, a somehow different approach had to be used to estimate the equation for Germany. Also, the specifications for Mexico and Spain were greatly improved by considering different import propensities for some expenditure components, in particular exports of goods and services for Mexico and private non-residential investment for Spain ${ }^{22}$. The equations perform well against standard diagnostics tests ${ }^{23}$. The only important diagnostic test that is failed at the 5 per cent significance level is a Chow breakpoint test for structural stability of the equation for Germany, which is explained by re-unification.

18. The sign and magnitude of the estimated coefficients (Table 1) are generally in accordance with economic theory with a few important exceptions. The exceptions are Korea, estimated with a wrongly signed long-run price elasticity, Ireland, where a long-run price elasticity close to zero was obtained, and Germany, where the instability effects caused by re-unification constitute a real econometric challenge. Correctly signed but not significant long-run price elasticities were obtained for the United Kingdom, the Netherlands, Portugal and Turkey. In general, difficulties in obtaining consistent and sensible estimates of long-run elasticities are signals and consequences of periods of rapid structural change, particularly in the case of Korea, Ireland, and Germany.

19. For example, in the current work the number of long run parameters of the model is reduced from 23 in the country by country equations to 11 in the pooled system.

20. The pooled parameters are in fact robust to changes affecting only one country of the pool.

21. With the exception of Luxembourg for which trade data were not available.

22. The equations and estimation results for Germany, Mexico, Spain, Poland, Hungary and Czech Republic are discussed in Annex 1.

23. All tests are passed to at least 10 per cent of significance. Ireland passes the Chow breakpoint test for structural stability with a p-value of 5.4 per cent. As to the Ramsey test for functional form, only Japan, Germany, United Kingdom and Switzerland fail it at the 10 per cent level, and only Japan and Germany at the 5 per cent (3.2 per cent and 2.6 per cent respective p-values). 
19. The obtained single country estimates of long-run demand elasticities are more concentrated than the single country estimates of long-run price elasticities (Figure 4). In particular, the majority of OECD countries shows estimated long-run demand elasticities ranging between 1.39 and 1.49. Manufacturing import volumes of the United States, Spain, Germany, Italy, France, and Portugal appear to have substantially above average long-run demand elasticities, while for Norway, Korea, Ireland, and (to a lesser extent) Finland substantially below average long-run demand elasticities are found. At least four clusters of countries showing the same long-run price elasticity are identified, with centers approximately equal to $-1.20,-1.0,-0.70$ and $-0.30^{24}$.

\section{Pooled results}

20. Following the single country estimation of equation [1], countries were pooled according to the procedure described in Section 2. Four countries (Germany, Ireland, Korea and Netherlands) for which economically plausible results were not obtained at the single country stage did not enter the estimation pool. Rather, at the end of the process they were tested to see if the common parameters were statistically acceptable $^{25}$. Testing against the pooled results, Germany accepts all common coefficients ${ }^{26}$. Ireland accepts all common coefficients except that for the long-run price elasticity, which was imposed at its maximum acceptable ${ }^{27}$ value (-0.10). Korea accepts all common short-run coefficients, and the long-run ones are either imposed at their maximum acceptable value (long-run price elasticity) or country specific (long-run demand elasticity and error correction term). A special case is Netherlands, for which robust estimates were obtained for the long-run demand elasticity but not for the long-run price elasticity. Netherlands was thus included in the pool for demand elasticity only and all the other coefficients ${ }^{28}$ were imposed. Other countries that do not enter the estimation pool are Mexico, Spain, Poland, Hungary and Czech Republic ${ }^{29}$. Mexico and Spain have been excluded by the pool estimation because their model specification is different from the one in equation [1]. Poland, Hungary and Czech Republic did not enter the estimation pool because data limitations undermine the reliability of estimated parameters.

21. The pooling procedure results in three common coefficients for the value of the long-run demand elasticity and four common coefficients for the long-run price elasticity and the error correction term respectively (Tables 2 and 3). As expected, the coefficient presenting the highest degree of concentration is the long-run demand elasticity, with 14 countries out of the 20 pooled sharing one common value (1.45). A relatively high degree of concentration is also found for the error correction coefficient, with 9 countries out of the 20 pooled sharing one common value $(-0.43)$. The dispersion is much higher in terms of the long-run price elasticity: OECD countries are almost equally distributed among the clustering centres ${ }^{30}$, and the centres more dispersed than the ones identified for the long-run demand elasticity or the error correction coefficient ${ }^{31}$.

24. The first cluster comprises Canada, Australia, Greece and Japan, the second comprises Switzerland, Sweden, and Spain, the third one includes the United States, Germany, Iceland, Norway, and Finland, and the fourth one the remaining OECD countries.

25. And in some cases these might be imposed even if not a valid restriction.

26. With the exception of the initially imposed value for the long-run demand elasticity, cfr. Annex 1.

27. At the 5 per cent significance level.

28. Price elasticity, error correction term and short-run coefficients.

29. Cfr. Annex 1 for more information.

30. The group with the biggest size for long-run price elasticity is made of six countries.

31. The standard deviation of the clustering centres for the long run price elasticity is 0.33 compared to 0.23 for the long run demand elasticity clustering centres and 0.20 for the error correction coefficient ones. 
22. Overall the results support the hypothesis of common long-run adjustment of OECD manufacturing import volumes to demand shocks. Estimated long-run demand elasticities are always bigger than one, with the United States, Hungary and Spain showing the largest estimated value (over 2). The hypothesis of common long-run adjustment of OECD manufacturing import volumes to relative price shocks is instead rejected by the data, with the estimated long-run price elasticities being significantly lower than one for about half of the OECD countries. Impact demand elasticities are more dispersed than impact price elasticities, despite the fact that the majority of countries is clustered around the value 1.70 (Table 4). Impact demand elasticities are generally substantially bigger than one, while impact price elasticities are substantially lower.

23. The estimates presented imply that manufacturing import volumes for the OECD area would increase by 0.8 percentage points following a permanent decrease of one percentage point of relative manufacturing import prices ${ }^{32}$. A shock of similar magnitude to total final expenditures would increase manufacturing import volumes for the OECD area by 1.8 percentage points, because the average demand elasticity of imports is higher than the average price elasticity. Two different tendencies characterise manufacturing import volumes dynamic adjustments to permanent shocks affecting relative import prices and demand (Figures 5 and 6). A permanent change in total final expenditures causes overshooting of import volumes for almost all countries, with the exception of Germany, Hungary, Ireland, Netherlands, Norway, and Spain. The adjustment pattern following a permanent change in relative import prices is smoother, with overshooting taking place only in Australia, Austria, Finland, Iceland, Ireland, Portugal, and Turkey. The greater short-run reactivity of import volumes to changes in final expenditures, compared to changes in relative prices, is common to other multi-country models ${ }^{33}$, and may be explained (together with overshooting phenomena) by supply constraints effective in the short-run ${ }^{34,35}$.

24. Following permanent shocks to relative import prices ${ }^{36}$, countries complete on average at least 50 per cent of the long-run adjustment within the first year, and at least 80 per cent of the adjustment within the first year and a half. The speed of adjustment of import volumes to a permanent change in relative import prices is however quicker for the majority of countries. In fact, 23 countries over 28 complete at least 50 per cent of the long-run adjustment in less than six months, and 18 countries complete at least 80 per cent of the long-run adjustment in less than one year.

\section{Conclusions}

25. The aim of this paper has been to test the hypothesis of common long-run responses across OECD countries of manufacturing import volumes to demand and relative price shocks, adopting a pooling procedure that allows this hypothesis to be tested on a "coefficient by coefficient" basis. The results broadly support the hypothesis of common long-run responses across OECD countries of manufacturing import volumes to demand shocks, while reject the hypothesis of common long-run responses to relative

32. Aggregates for the OECD area are computed as the weighted average of the single country values, with weights equal to the ones reported in the OECD Economic Outlook No. 69, 2001, page 226, table "Weighting scheme for aggregate measures".

33. Cfr. for example Laxton et al. 1998.

34. The central point is that both final expenditures and stocks are pro-cyclical variables. National production may thus have difficulties at reacting in the short-run to positive demand shocks (especially when capacity limits are close), while negative demand shocks may build on a preference for national goods.

35. Note that overshooting of import volumes is judgementally eliminated in the IMF Multimod model (Laxton et al. 1998).

36. Note that, due to general presence of overshooting, such considerations are meaningless in the case of shocks to final expenditures. 
price shocks. Estimated long-run and impact demand elasticities are generally bigger than one, and also bigger than long-run and impact price elasticities, whose estimated values imply a less than proportional adjustment of manufacturing import volumes. According to the estimates presented here, manufacturing import volumes for the OECD area would increase by 0.8 percentage points following a permanent decrease of one percentage point of relative manufacturing import prices. A shock of similar magnitude to total final expenditures would instead increase manufacturing import volumes for the OECD area by 1.8 percentage points. 


\section{BIBLIOGRAPHY}

BAJO-RUBIO O. and C. LOPEZ-PUEYO (1997),

"An industry analysis of foreign direct investment in Spanish manufacturing, 1986-1992",

(November).

DOMENECH R. and D. TAGUAS (1997),

"Exportaciones e Importaciones de bienes y sericios en la economia española", Direccion General de Analisis y Programacion Presupuestaria Documento de Trabajo, (July).

HOOPER P., K. JOHNSON and J. MARQUEZ (1998),

"Trade elasticities for G-7 countries", International Finance Discussion Paper No. 609, (April), Federal Reserve Board.

LAXTON D., P. ISARD, H. FARUQEE, E. PRASAD, and B.TURTELBOOM (1998),

"Multimod Mark III - the core dynamic and steady state models", IMF Occasional Paper No. 164, (May).

MURATA K., D.TURNER and L. LE FOULER (1998),

"Further work on Interlink manufacturing export volume equations", OECD internal report, (November).

MURATA K., D.TURNER, D. RAE and L. LE FOULER (2000),

"Modelling manufacturing export volumes equations: a system estimation approach", $O E C D$

Economics Department Working Paper No. 235.

OECD (1999),

Economic Survey of Mexico.

OECD (1986),

Economic Survey of Japan.

OECD (2001),

Economic Outlook No. 69.

PESARAN H., Y. SHIN and R. SMITH (1999),

"Pooled mean group estimation of dynamic heterogeneous panels", Journal of the American

Statistical Association, Vol. 94, No. 446 (June).

RICHARDSON P. (ed.) (1997)

"Globalisation and linkages: macro-structural challenges and opportunities", OECD Economics Department Working Paper No. 181.

RICHARDSON P. (1988),

“The Structure and Simulation Properties of OECD's INTERLINK Model”, OECD Economic Studies No. 10, (Spring). 
Figure 1. World output growth and world merchandise trade growth (five-year averages)

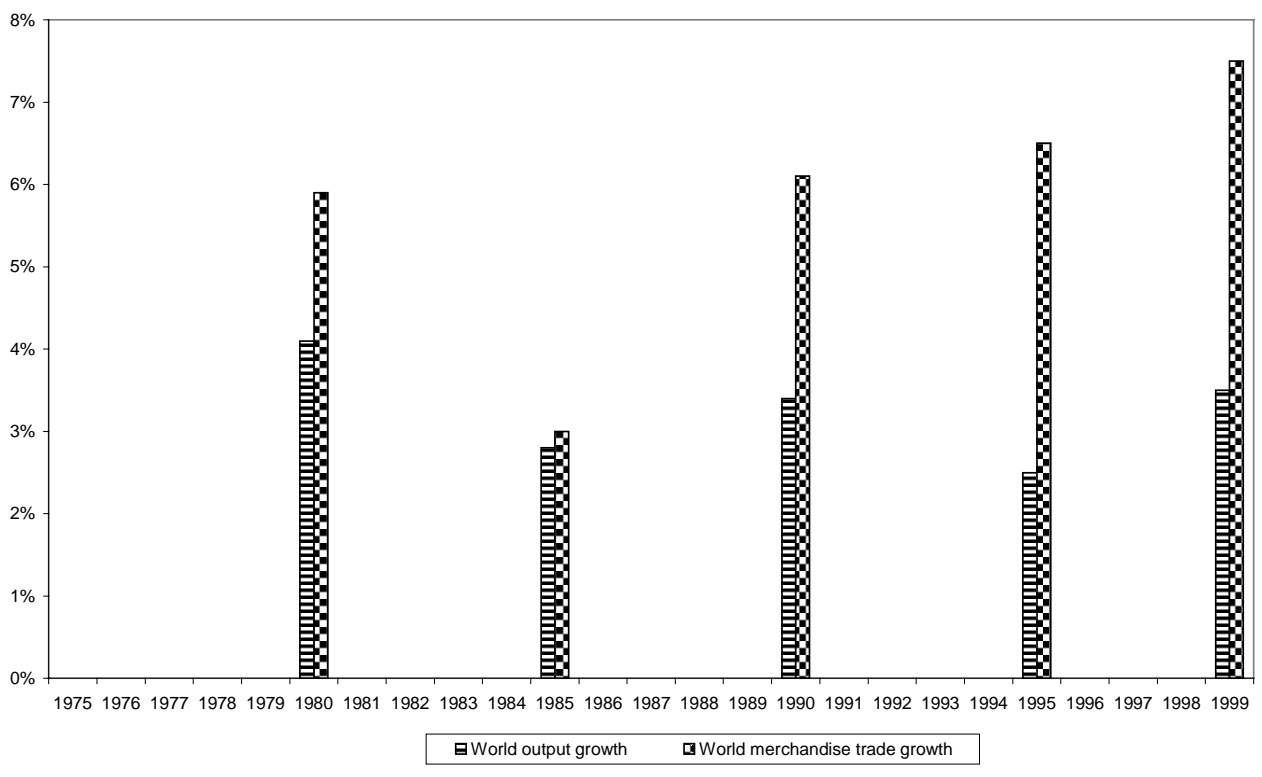

Figure 2. World manufacturing trade as a share of world merchandise trade

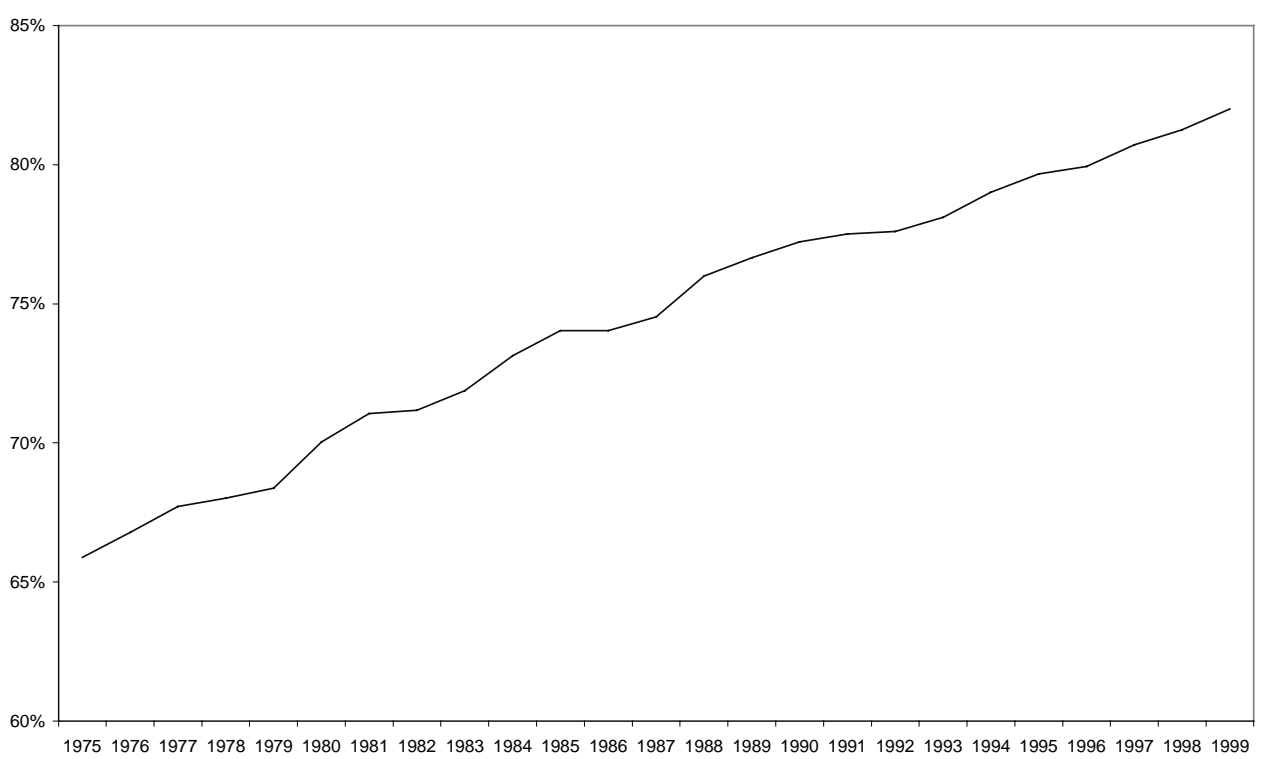


Figure 3. Manufacturing imports as a percentage of GDP, G-7 countries

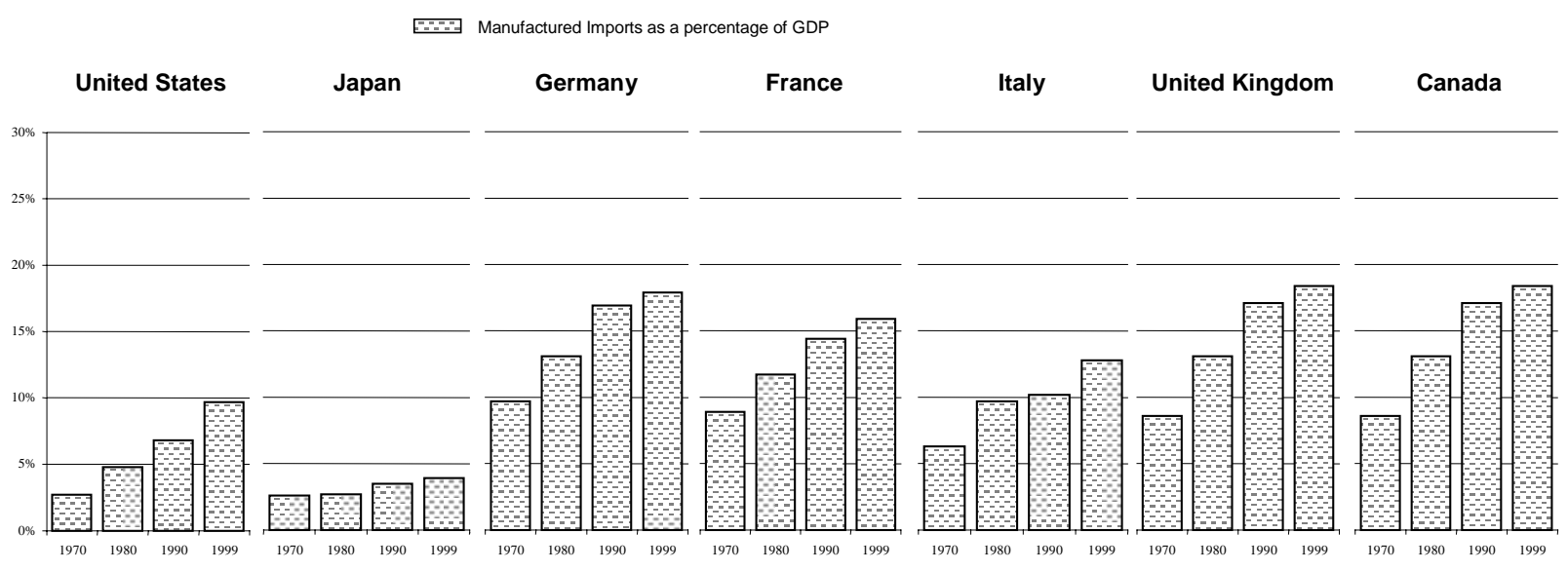

Figure 4. Single country estimates of long-run demand and price elasticities, deviations from the average

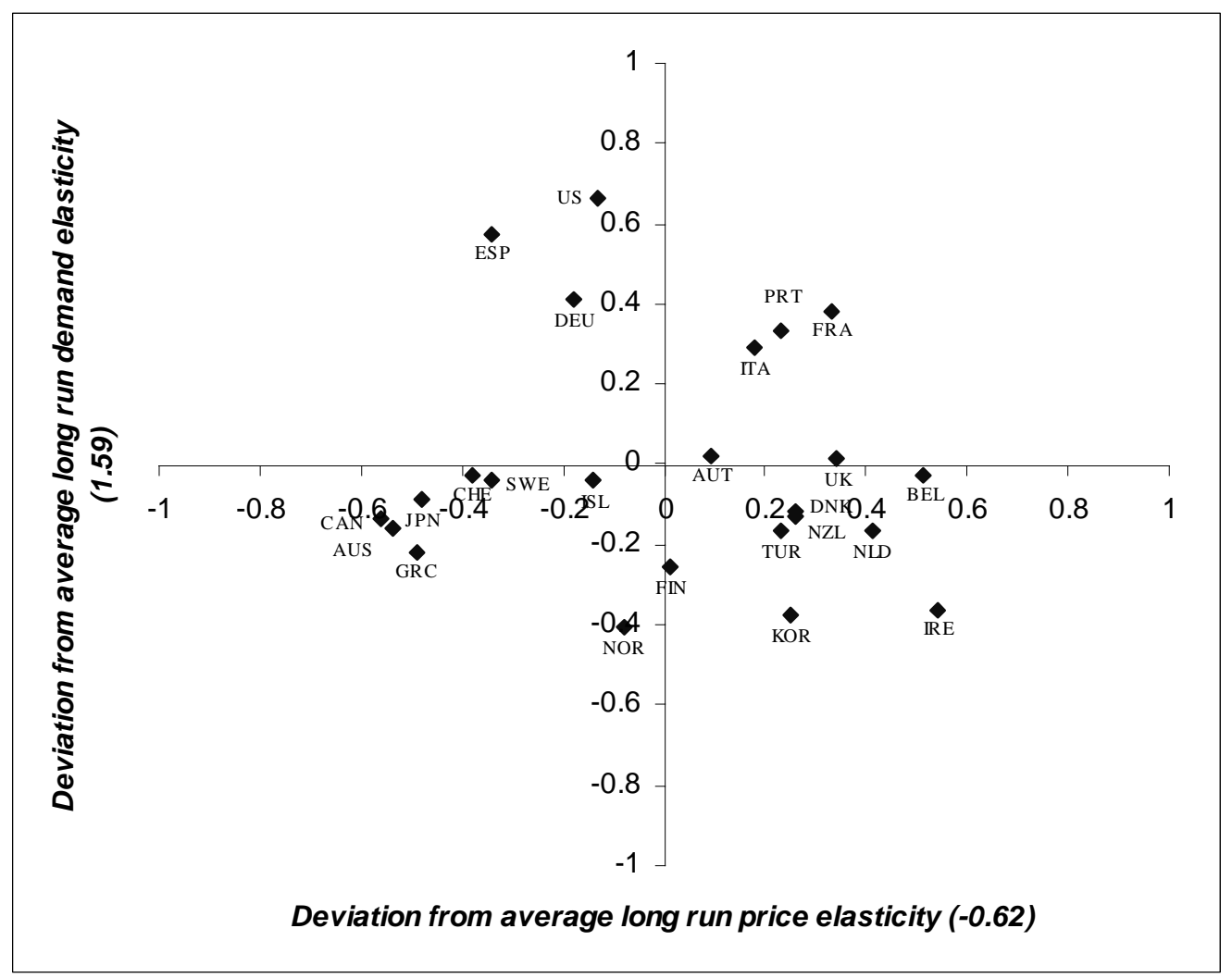


Figure 5. The response of manufacturing import volumes to one percentage point increase in final expenditures
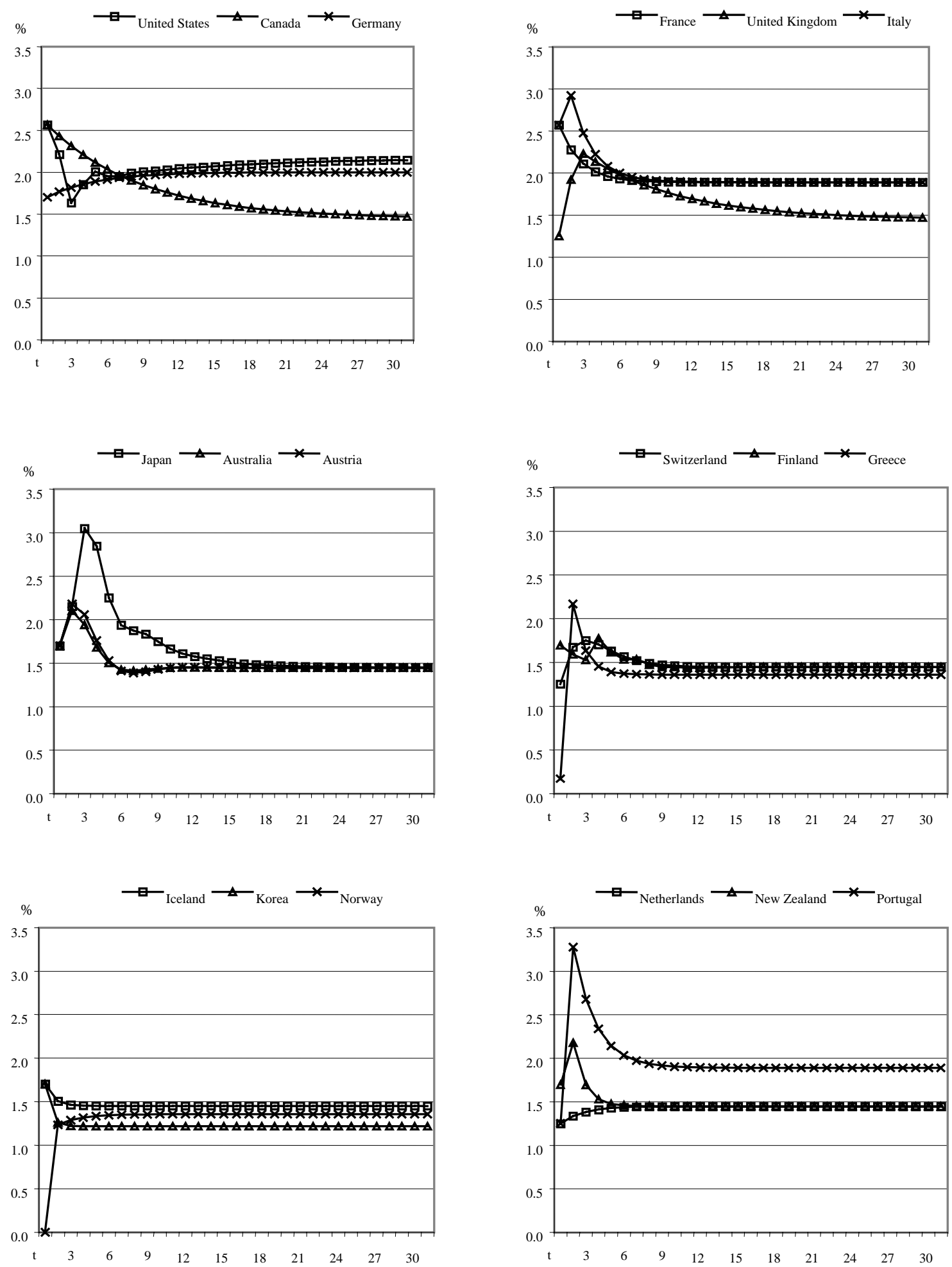
Figure 5 (continued). The response of manufacturing import volumes to one percentage point increase in final expenditures
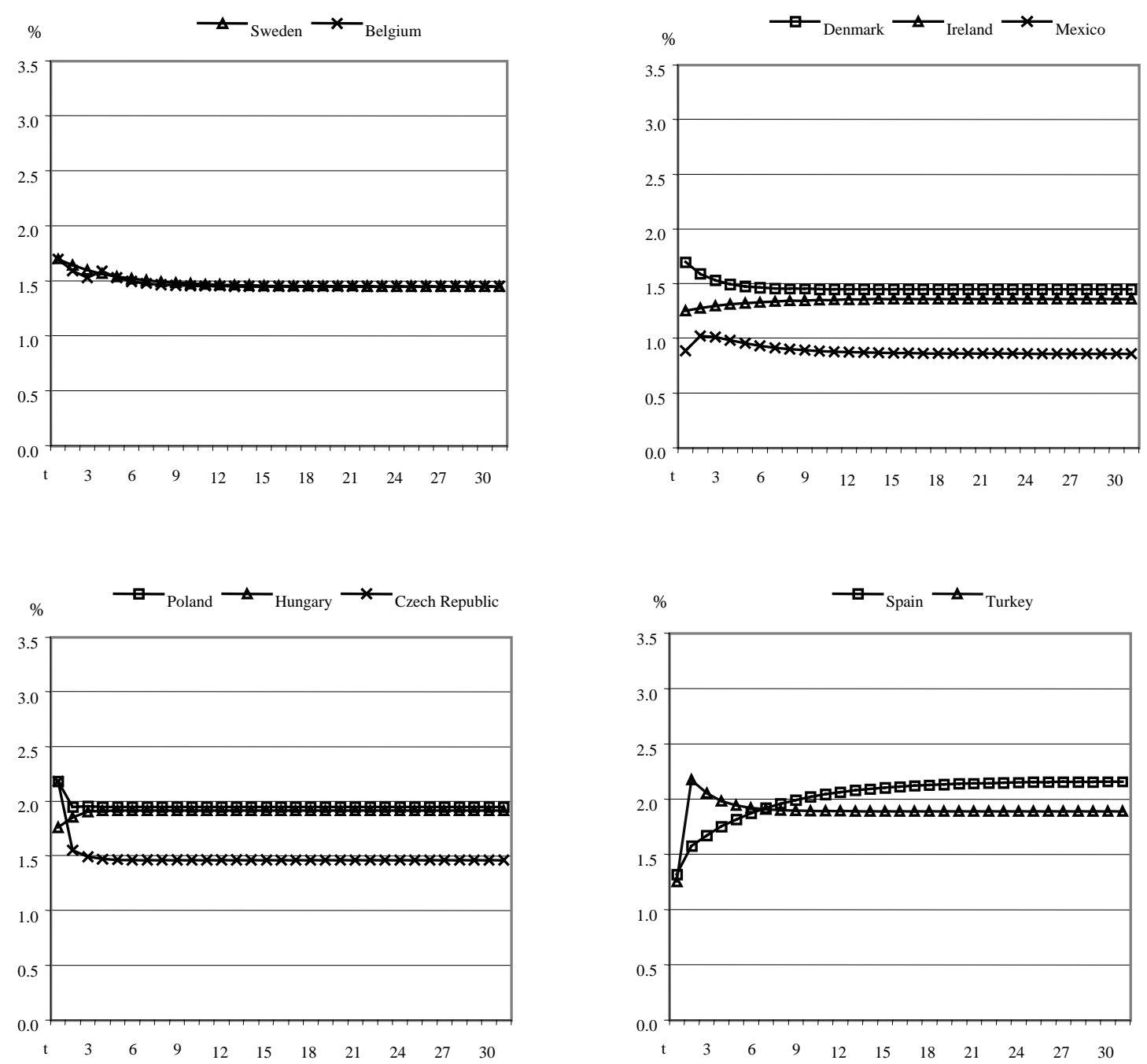
Figure 6. The response of manufacturing import volumes to one percentage point increase in relative import prices
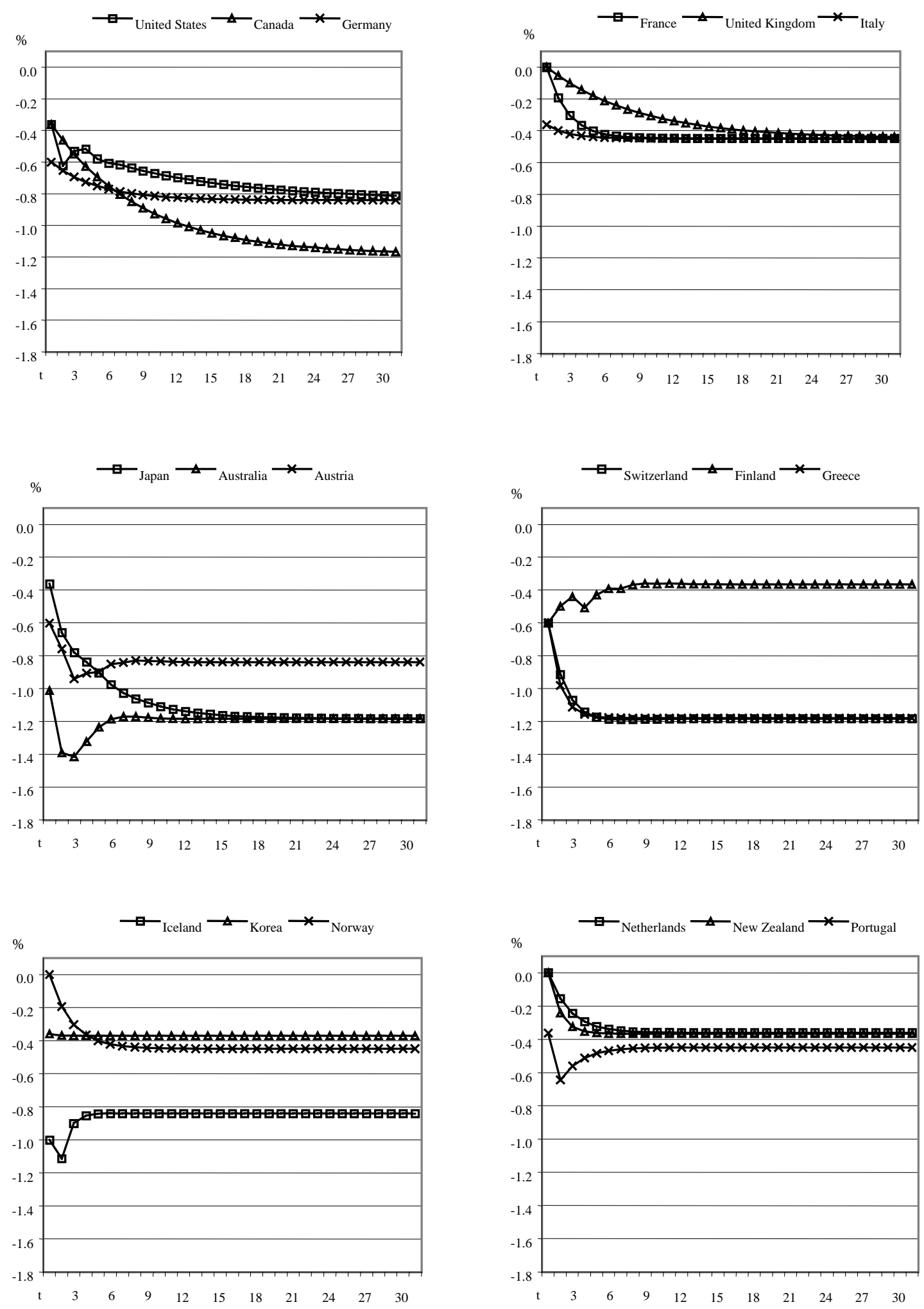
Figure 6 (continued). The response of manufacturing import volumes to one percentage point increase in relative import prices
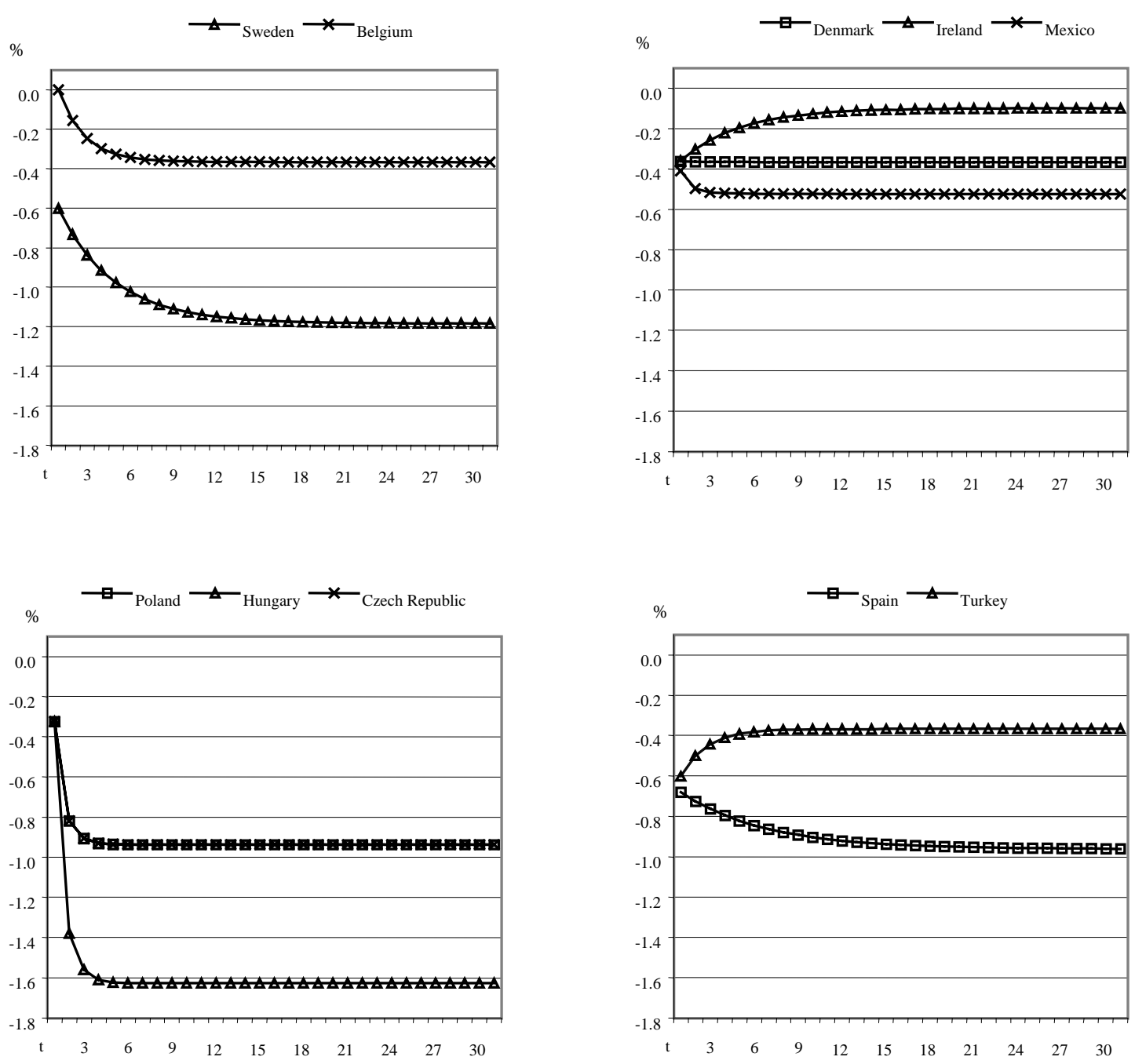
Table 1. Single countries estimates - key parameters

\begin{tabular}{lcc}
\hline & LR elasticity prices & LR elasticity demand \\
\hline United States & -0.75 & 2.25 \\
Japan & -1.1 & 1.50 \\
Germany & $-0.80^{2}$ & $2^{2}$ \\
France & -0.29 & 1.97 \\
Italy & -0.44 & 1.88 \\
United Kingdom & $-0.28^{1}$ & 1.6 \\
Canada & -1.18 & 1.45 \\
Average & -0.69 & 1.81 \\
\hline & & \\
Australia & -1.16 & 1.43 \\
Austria & -0.53 & 1.61 \\
Belgium & -0.11 & 1.56 \\
Denmark & -0.36 & 1.46 \\
Finland & -0.61 & 1.33 \\
Greece & -1.11 & 1.37 \\
Iceland & -0.76 & 1.55 \\
Ireland & $-0.08^{1}$ & 1.22 \\
Korea & $-0.37^{2}$ & 1.21 \\
Netherlands & $-0.21^{1}$ & 1.42 \\
New Zealand & -0.36 & 1.47 \\
Norway & -0.70 & 1.18 \\
Portugal & $-0.39^{1}$ & 1.92 \\
Spain & -0.96 & 2.16 \\
Sweden & -0.96 & 1.55 \\
Switzerland & -1 & 1.56 \\
Turkey & $-0.39^{1}$ & 1.42 \\
Average & -0.58 & 1.49 \\
\hline
\end{tabular}

1. Not significant at the 10 per cent level.

2. Imposed coefficient.

3. The equation for Spain is based on different short-run import elasticities for total expenditures and private nonresidential investment. 
Table 2. Key pooled coefficients and countries

\begin{tabular}{|c|c|c|}
\hline Coefficients & Pooled countries & Country-specific coefficient for: \\
\hline $\begin{array}{l}\text { Long-run demand elasticity: } \\
1^{\text {st }} \text { common coefficient }=1.45\end{array}$ & $\begin{array}{l}\text { Japan, United Kingdom, Canada, } \\
\text { Australia, Austria, Belgium, Switzerland, } \\
\text { Denmark, Finland, Iceland, Netherlands, } \\
\text { New Zealand, Sweden, Turkey }\end{array}$ & $\begin{array}{l}\text { United States }=2.17, \text { Germany }=2.00 \\
(\text { imposed), Spain }=2.16, \text { Korea }=1.22, \\
\text { Mexico }=1.18, \text { Poland }=1.95, \\
\text { Hungary }=1.92, \text { Czech Republic }=1.46\end{array}$ \\
\hline $\begin{array}{l}\text { Long-run demand elasticity: } \\
2^{\text {nd }} \text { common coefficient }=1.89\end{array}$ & France, Italy, Portugal & \\
\hline $\begin{array}{l}\text { Long-run demand elasticity: } \\
3^{\text {rd }} \text { common coefficient }=1.36\end{array}$ & Greece, Norway, Ireland (imposed) & \\
\hline $\begin{array}{l}\text { Long-run price elasticity: } \\
1^{\text {st }} \text { common coefficient }=-0.84\end{array}$ & $\begin{array}{l}\text { United States, Austria, Iceland, Germany } \\
\text { (imposed) }\end{array}$ & $\begin{array}{l}\text { Korea }=-0.37 \text { (imposed), Ireland }=-0.10 \\
(\text { imposed), Spain }=-0.96, \text { Mexico }=-0.52, \\
\text { Poland }=-0.94, \text { Hungary }=-1,63, \text { Czech } \\
\text { Republic }=-0.94\end{array}$ \\
\hline $\begin{array}{l}\text { Long-run price elasticity: } \\
2^{\text {nd }} \text { common coefficient }=-0.45\end{array}$ & $\begin{array}{l}\text { Norway, Italy, Portugal, France, United } \\
\text { Kingdom }\end{array}$ & \\
\hline $\begin{array}{l}\text { Long-run price elasticity: } \\
3^{\text {rd }} \text { common coefficient }=-1.18\end{array}$ & $\begin{array}{l}\text { Sweden, Canada, Japan, Switzerland, } \\
\text { Greece, Australia }\end{array}$ & \\
\hline $\begin{array}{l}\text { Long-run price elasticity: } \\
4^{\text {th }} \text { common coefficient }=-0.36\end{array}$ & $\begin{array}{l}\text { New Zealand, Turkey, Denmark, } \\
\text { Finland, Belgium, Netherlands (imposed) }\end{array}$ & \\
\hline $\begin{array}{l}\text { Error correction term: } \\
1^{\text {st }} \text { common coefficient }=-0.43\end{array}$ & $\begin{array}{l}\text { Belgium, Norway, Australia, Portugal, } \\
\text { France, Italy, Denmark, Finland, } \\
\text { Netherlands (imposed) }\end{array}$ & $\begin{array}{l}\text { Spain }=-0.16, \text { Iceland }=-0.78, \\
\text { Korea }=-0.91, \text { Mexico }=-0.19, \text { Poland, } \\
\text { Hungary, Czech Republic }=-0.81\end{array}$ \\
\hline $\begin{array}{l}\text { Error correction term: } \\
2^{\text {nd }} \text { common coefficient }=-0.22\end{array}$ & $\begin{array}{l}\text { Turkey, Japan, Sweden, Switzerland, } \\
\text { Germany (imposed), Ireland (imposed) }\end{array}$ & \\
\hline $\begin{array}{l}\text { Error correction term: } \\
3^{\text {rd }} \text { common coefficient }=-0.66\end{array}$ & Austria, Greece, New Zealand & \\
\hline $\begin{array}{l}\text { Error correction term: } \\
4^{\text {th }} \text { common coefficient }=-0.12\end{array}$ & Canada, United States, United Kingdom & \\
\hline $\begin{array}{l}\text { Short-run demand elasticity: } \\
1^{\text {st }} \text { common coefficient }=1.70\end{array}$ & $\begin{array}{l}\text { Germany (imposed), Japan, Australia, } \\
\text { Austria, Finland, Iceland, Korea } \\
\text { (imposed), New Zealand, Sweden, } \\
\text { Belgium, Denmark }\end{array}$ & $\begin{array}{l}\text { Spain }=2.24, \text { Greece }=0.17, \text { Mexico }=1.48 \\
\text { Poland }=2.18, \text { Hungary }{ }^{1}=2.77, \text { Czech } \\
\text { Republic }=2.18\end{array}$ \\
\hline $\begin{array}{l}\text { Short-run demand elasticity: } \\
2^{\text {nd }} \text { common coefficient }=2.57\end{array}$ & United States, Canada, France, Italy & \\
\hline $\begin{array}{l}\text { Short-run demand elasticity: } \\
3^{\text {rd }} \text { common coefficient }=1.25\end{array}$ & $\begin{array}{l}\text { United Kingdom, Switzerland, } \\
\text { Netherlands (imposed), Portugal, Turkey, } \\
\text { Ireland (imposed) }\end{array}$ & \\
\hline $\begin{array}{l}\text { Short-run price elasticity: } \\
1^{\text {st }} \text { common coefficient }=-0.60\end{array}$ & $\begin{array}{l}\text { Germany (imposed), Austria, } \\
\text { Switzerland, Finland, Greece, Turkey, } \\
\text { Sweden }\end{array}$ & $\begin{array}{l}\text { Spain }=-0.68, \text { Mexico }=-0.41 ; \text { Poland, } \\
\text { Hungary, Czech Republic }=-0.32\end{array}$ \\
\hline $\begin{array}{l}\text { Short-run price elasticity: } \\
2^{\text {nd }} \text { common coefficient }=-0.36\end{array}$ & $\begin{array}{l}\text { United States, Canada, Italy, Japan, } \\
\text { Korea (imposed), Portugal, Denmark, } \\
\text { Ireland (imposed) }\end{array}$ & \\
\hline $\begin{array}{l}\text { Short-run price elasticity: } \\
3^{\text {rd }} \text { common coefficient }=-1.00\end{array}$ & Australia, Iceland & \\
\hline
\end{tabular}

1. The reported elasticity for Hungary refers to total domestic expenditures. 
Table 3. Pooled estimates - key parameters

\begin{tabular}{lcc}
\hline Pooled estimates & LR elasticity prices & LR elasticity demand \\
\hline United States & -0.84 & 2.17 \\
Japan & -1.18 & 1.45 \\
Germany & $-0.84^{1}$ & $2^{1}$ \\
France & -0.45 & 1.89 \\
Italy & -0.45 & 1.89 \\
United Kingdom & -0.45 & 1.45 \\
Canada & -1.18 & 1.45 \\
Average & -0.77 & 1.76 \\
\hline & & \\
Australia & -1.18 & 1.45 \\
Austria & -0.84 & 1.45 \\
Belgium & -0.36 & 1.45 \\
Denmark & -0.36 & 1.45 \\
Finland & -0.36 & 1.45 \\
Greece & -1.18 & 1.36 \\
Iceland & -0.84 & 1.45 \\
Ireland & $-0.10^{1}$ & $1.36^{1}$ \\
Korea & $-0.37^{1}$ & $1.22^{2}$ \\
Netherlands & $-0.36^{1}$ & 1.45 \\
New Zealand & -0.36 & 1.45 \\
Norway & -0.45 & 1.36 \\
Portugal & -0.45 & 1.89 \\
Sweden & -1.18 & 1.45 \\
Switzerland & -1.18 & 1.45 \\
Turkey & -0.36 & 1.45 \\
Average & -0.62 & 1.45 \\
\hline
\end{tabular}

1. Imposed values.

2. Country specific. 
Table 4. Short-run pooled elasticities

\begin{tabular}{|c|c|c|c|c|}
\hline & $\begin{array}{c}\text { Short-run } \\
\text { demand elasticity }\end{array}$ & $\begin{array}{c}\text { Long-run demand } \\
\text { elasticity }\end{array}$ & $\begin{array}{c}\text { Short-run price } \\
\text { elasticity }\end{array}$ & $\begin{array}{l}\text { Long-run price } \\
\text { elasticity }\end{array}$ \\
\hline United States & 2.57 & 2.17 & -0.36 & -0.84 \\
\hline Japan & 1.70 & 1.45 & -0.36 & -1.18 \\
\hline Germany & 1.70 & 2.00 & -0.60 & -0.84 \\
\hline France & 2.57 & 1.89 & $(-0.21)$ & -0.45 \\
\hline Italy & 2.57 & 1.89 & -0.36 & -0.45 \\
\hline United Kingdom & 1.25 & 1.45 & $(-0.06)$ & -0.45 \\
\hline Canada & 2.57 & 1.45 & -0.36 & -1.18 \\
\hline Australia & 1.70 & 1.45 & -1.00 & -1.18 \\
\hline Austria & 1.70 & 1.45 & -0.60 & -0.84 \\
\hline Belgium & 1.70 & 1.45 & $(-0.15)$ & -0.36 \\
\hline Czech Republic & 2.18 & 1.46 & -0.32 & -0.94 \\
\hline Denmark & 1.70 & 1.45 & -0.36 & -0.36 \\
\hline Finland & 1.70 & 1.45 & -0.60 & -0.36 \\
\hline Greece & 0.17 & 1.36 & -0.60 & -1.18 \\
\hline Hungary $^{l}$ & 2.77 & 1.92 & -0.32 & -1.63 \\
\hline Iceland & 1.70 & 1.45 & -1.00 & -0.84 \\
\hline Ireland & 1.25 & 1.36 & -0.36 & -0.10 \\
\hline Korea & 1.70 & 1.22 & -0.36 & -0.37 \\
\hline Mexico $^{2}$ & 1.48 & 1.18 & -0.41 & -0.52 \\
\hline Netherlands & 1.25 & 1.45 & $(-0.15)$ & -0.36 \\
\hline New Zealand & 1.70 & 1.45 & $(-0.21)$ & -0.36 \\
\hline Norway & $(1.21)$ & 1.36 & $(-0.21)$ & -0.45 \\
\hline Poland & 2.18 & 1.95 & -0.32 & -0.94 \\
\hline Portugal & 1.25 & 1.89 & -0.36 & -0.45 \\
\hline Spain $^{3}$ & 2.24 & 2.16 & -0.68 & -0.96 \\
\hline Switzerland & 1.25 & 1.45 & -0.60 & -1.18 \\
\hline Sweden & 1.70 & 1.45 & -0.60 & -1.18 \\
\hline Turkey & 1.25 & 1.45 & -0.60 & -0.36 \\
\hline
\end{tabular}

Note: Figures in brackets are impact elasticities rather than short-run elasticities. While short-run elasticities measure the effect at time $t$ of a shock happening at time $t$, impact elasticities measure the current effect of the most recent shock (not necessarily happened at time $\mathrm{t}$ ). Impact elasticities are reported for those countries whose short-run elasticities are equal to zero.

1. Short-run elasticitiy to total domestic expenditures.

2. Long and short-run demand elasticities to total expenditures.

2. Short-run elasticity to total expenditures minus private non-residential investment. 
ECO/WKP(2001)37

\section{ANNEX: ESTIMATION PROCEDURE AND RESULTS FOR GERMANY, MEXICO, SPAIN, POLAND, HUNGARY AND CZECH REPUBLIC}

\section{Germany}

1. Coincident with re-unification, the manufacturing import content of total expenditure for Germany shows an abrupt shift in $\operatorname{trend}^{37}$ (Figure 1.1). This suggests both the inclusion of a shift dummy for the trend change and the inclusion of specific dummies for some post re-unification years. However, correcting with dummies for re-unification outliers amounts to disregard the information concerning that period, and thus leaves very little information about more recent developments. It was thus necessary to choose between basing the estimates on pre-unification history only or adopting a more judgmental approach to take these into account and get "full sample" estimates. The second approach was used, which meant imposing a value for the long-run demand elasticity ${ }^{38}$ and then testing if common values could be imposed for the other coefficients. As it happens, Germany shares most of the common coefficients.

\section{Mexico}

2. The standard specification for Mexico does not identify a stable long-run relationship. Investigation of the possible causes of such instability suggested that Mexican imports have an exceptionally high export content ${ }^{39}$. The distinction between the import demand for domestic final expenditures and exports of goods and services proved to be significant and enabled a stable model to be estimated, taking the following form:

$$
\begin{aligned}
& \Delta \ln M M V_{t}=\alpha_{0}+\beta_{1} \Delta \ln M M V_{t-1}+\beta_{2} \Delta \ln T E V_{t}+\beta_{3} \Delta \ln X G S V_{t}+\gamma_{1} \Delta \ln R P M_{t} \\
& +\delta_{1}\left(\ln M M V_{t-1}-\delta_{2} \ln T E V_{t-1}-\delta_{3} \ln X G S V_{t-1}-\delta_{4} \ln R P M_{t-1}\right)
\end{aligned}
$$

Variables definitions are as in Section 1 of the main text and:

TEV $=$ Total Expenditure, volume

XGSV $=$ Exports of Goods and Services, volume

37. Note also that the semi-annual growth rate of manufactured goods import volumes moved from 12 per cent in 1990, second semester, to -16 per cent in 1993, first semester. Aggregate demand and relative prices also show a degree of variability in the same years, but not comparable to the one for import volumes.

38. The value has been determined on the basis of both the pooled results and the relative position of Germany in terms of long-run demand elasticity according to previous estimates.

39. From the "OECD Economic Surveys - Mexico" (1999): "Intermediate goods make up 77 per cent of total imports - with export-related intermediate goods accounting for the largest share (one-half of total imports) - while capital goods are 14 per cent of the total and consumption goods are only 9 per cent. More than half of total Mexican imports are accounted for by export-related intermediate goods". 
3. In this specification $\beta_{3}$ is the short-run and $\delta_{3}$ is the long-run import elasticity to exports.

The OLS-single country estimated coefficients are ${ }^{40}$ :

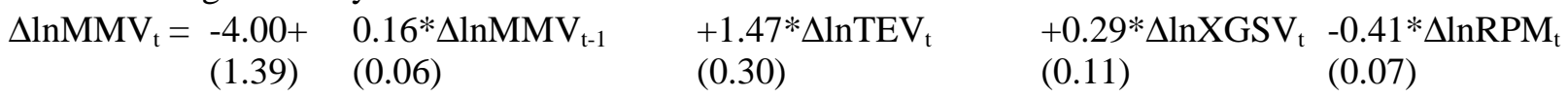

$$
\begin{aligned}
& -0.19 *\left(\operatorname{lnMMV}_{\mathrm{t}-1}+1.16 * \operatorname{lnTEV}_{\mathrm{t}-1} \quad+0.55 * \ln \mathrm{XGSV}_{\mathrm{t}-1}-0.53 * \operatorname{lnRPM}_{\mathrm{t}-1}\right) \\
& \begin{array}{llll}
(0.06) & (0.34) & (0.15)
\end{array} \\
& \text { Num. of observations }=58 \quad \text { R-squared }=0.92 \quad \text { Adjusted R-squared }=0.91 \quad \text { S.E. }=0.04
\end{aligned}
$$

The equation performs well against standard diagnostics tests, passing all of them at the 10 per cent significance level at least.

4. The estimated elasticities are in line with the single country estimates for other OECD countries. Computation of import propensities also confirms the greater sensitivity of Mexican manufacturing imports to exports than to domestic demand ( 0.38 on average for exports compared to 0.25 for total expenditures $)^{41}$.

\section{Spain}

5. Estimating equation [1] for Spain produced an unplausibly high value for the short-run demand elasticity (around 4). The equation, however, did not show any evident sign of miss-specification and estimated coefficients proved to be robust to both the sample period and the lag structure. As such, the possibility of a different specification, especially in terms of import propensities, was explored. Among all components, private non-residential investment has been found to have a significantly different import propensity, although in the short-run only. A possible explanation for this is given by the importance of Foreign Direct Investments, which have experienced a substantial acceleration since the early $1980 \mathrm{~s}^{42}$ and which empirical studies have found to have a strong effect on Spanish imports ${ }^{43}$.

6. The form of the estimated equation for Spain is thus:

$$
\begin{aligned}
& \Delta \ln M M V_{t}=\alpha_{0}+\beta_{1} \Delta \ln T E V X I_{t}+\beta_{2} \Delta \ln I V B_{t}+\beta_{3} \Delta \ln I V B_{t-1}+\gamma_{1} \Delta \ln R P M_{t} \\
& +\delta_{1}\left(\ln M M V_{t-1}-\delta_{2} \ln T E V X_{t-1}-\delta_{3} \ln R P M_{t-1}\right)
\end{aligned}
$$

where all variables are as defined in Section 1 of the main text except:

TEVXI $=$ TEVX - IBV $=$ Total expenditure minus private non-residential fixed capital formation, volume $\mathrm{IBV}=$ private non-residential fixed capital formation, volume

40. Standard errors in brackets.

41. Import propensities to exports (domestic demand) are computed as the product of the export (domestic demand) elasticity by the ratio between imports and exports (domestic demand) volumes.

42. Cfr. Bajo-Rubio and Lopez-Pueyo, 1997.

43. Cfr. Domenech and Taguas ,1997. 
The OLS-single country estimated coefficients are ${ }^{44}$ :

\begin{tabular}{|c|c|c|c|c|c|}
\hline$\Delta \operatorname{lnMMV} V_{t}=$ & $\begin{array}{l}-6.37+ \\
(2.57)\end{array}$ & $\begin{array}{l}2.24 * \Delta \ln \mathrm{TEVXI}_{\mathrm{t}} \\
(0.65)\end{array}$ & $\begin{array}{l}+0.39 * \Delta \ln I B V_{t} \\
(0.11)\end{array}$ & $\begin{array}{l}+0.24^{*} \Delta \operatorname{lnIBV} V_{t-1} \\
(0.17)\end{array}$ & $\begin{array}{l}-0.68^{*} \Delta \ln R P M_{t} \\
(0.14)\end{array}$ \\
\hline & $\begin{array}{l}-0.16^{*}( \\
(0.04)\end{array}$ & $\begin{array}{c}\mathrm{MMV}_{\mathrm{t}-1}+2.16^{*} \ln 7 \\
(0.34)\end{array}$ & $\begin{array}{ll}\mathrm{EVX}_{\mathrm{t}-1} & -0.96 * \ln \\
& (0.51)\end{array}$ & $\left.\mathrm{PM}_{\mathrm{t}-1}\right)$ & \\
\hline
\end{tabular}

Num. of observations $=62 \quad$ R-squared $=0.80 \quad$ Adjusted R-squared $=0.77 \quad$ S.E. $=0.03$

The equation performs well against standard diagnostics tests, passing all of them at the 10 per cent significance level at least.

7. The estimated elasticities are in line with the single country estimates for other OECD countries. For example, a one percentage point increase in total final expenditure (including investment) causes an immediate increase of manufacturing import volumes of 1.3 percentage points ${ }^{45}$. Computation of import propensities confirms the greater sensitivity of Spanish manufacturing imports to private non-residential investment than to domestic demand ( 0.40 on average for investment compared to 0.18 for total domestic demand).

\section{Poland, Hungary and Czech Republic}

8. Serious data limitations (data are at best available from 1990 onwards) prevent the single country-OLS estimation of import equations for Poland, Hungary and Czech Republic. It has thus been decided to pool together the equations for these countries and estimate a very simple dynamic model ${ }^{46}$ imposing a priori common coefficients for all parameters except the constant and the long-run demand elasticity. Some evidence was found suggesting that demand responses in Hungary might be substantially stronger than in the other countries. To take this into account, the equation for Hungary is based on different short-run elasticities for total domestic expenditures and exports ${ }^{47}$, and the long-run demand and price elasticities are country specific. The only pooled coefficients of the equation for Hungary are thus for the lagged dependent variable, the short-run price elasticity, and the error correction term.

9. The form of the estimated equations for Poland and the Czech Republic is:

$$
\begin{aligned}
& \Delta \ln M M V_{j t}=\alpha_{j}+\beta_{1} \Delta \ln M M V_{t-1}+\beta_{2} \Delta \ln T E V X_{t}+\gamma_{1} \Delta \ln R P M_{t} \\
& +\delta_{1}\left(\ln M M V_{t-1}-\delta_{2 j} \ln T E V X_{t-1}-\delta_{3} \ln R P M_{t-1}\right)
\end{aligned}
$$

where $\mathrm{j}=$ Poland, Czech Republic

\footnotetext{
44. Standard errors in brackets.

45. The average effect for OECD countries is 1.7 percentage points.

46. Even pooling together the observations does not provide a sufficient number of observations for robust statistical inferences.

47. The possibility of different import elasticities to domestic demand and exports was suggested by Andrew Burns. This hypothesis was rejected by long run coefficients but accepted by short run ones.
} 
and for Hungary is:

$$
\begin{aligned}
& \Delta \ln M M V_{k t}=\alpha_{j}+\beta_{1} \Delta \ln M M V_{t-1}+\beta_{2 k} \Delta \ln T D D V_{t}+\beta_{3 k} \Delta \ln X G S V_{t}+\gamma_{1} \Delta \ln R P M_{t} \\
& +\delta_{1}\left(\ln M M V_{t-1}-\delta_{2 k} \ln T E V X_{t-1}-\delta_{3 k} \ln R P M_{t-1}\right)
\end{aligned}
$$

The OLS estimated coefficients ${ }^{48}$ are:

\begin{tabular}{|c|c|c|c|}
\hline & Poland & Hungary & Czech Republic \\
\hline Constant & $\begin{array}{r}-22.14 \\
(6.83)\end{array}$ & $\begin{array}{l}-23.37 \\
(10.29)\end{array}$ & $\begin{array}{r}-11.91 \\
(5.60)\end{array}$ \\
\hline$\Delta \operatorname{lnMMV}_{\mathrm{t}-1}$ & $\begin{array}{l}-0.02 \\
(0.10)\end{array}$ & $\begin{array}{l}-0.02 \\
(0.10)\end{array}$ & $\begin{array}{l}-0.02 \\
(0.10)\end{array}$ \\
\hline$\Delta \operatorname{lnTEVX_{t}{}^{1}}$ & $\begin{array}{l}2.18 \\
(0.67)\end{array}$ & $\begin{array}{c}2.77 \\
(0.69)\end{array}$ & $\begin{array}{l}2.18 \\
(0.67)\end{array}$ \\
\hline$\Delta \ln X G S V_{t}$ & - & $\begin{array}{c}0.75 \\
(0.35)\end{array}$ & - \\
\hline$\Delta \ln P_{t}$ & $\begin{array}{l}-0.32 \\
(0.44)\end{array}$ & $\begin{array}{l}-0.32 \\
(0.44)\end{array}$ & $\begin{array}{l}-0.32 \\
(0.44)\end{array}$ \\
\hline Error correction coefficient & $\begin{array}{l}-0.81 \\
(0.16)\end{array}$ & $\begin{array}{l}-0.81 \\
(0.16)\end{array}$ & $\begin{array}{l}-0.81 \\
(0.16)\end{array}$ \\
\hline Long-run demand elasticity & $\begin{array}{c}1.95 \\
(0.38)\end{array}$ & $\begin{array}{c}1.92 \\
(0.32)\end{array}$ & $\begin{array}{c}1.46 \\
(0.27)\end{array}$ \\
\hline Long-run price elasticity & $\begin{array}{l}-0.94 \\
(0.33)\end{array}$ & $\begin{array}{l}-1.63 \\
(0.54)\end{array}$ & $\begin{array}{l}-0.94 \\
(0.33)\end{array}$ \\
\hline Number of system observations & & 37 & \\
\hline
\end{tabular}

\section{OLS estimated coefficients for Poland, Hungary and Czech Republic}

1. $\quad \Delta$ InTDDV $V_{t}$ for Hungary

All estimated elasticities, with the exception of the long-run price elasticity for Hungary, are in line with the single country estimates for other OECD countries.

48. Estimating the system with SURE did not change the coefficients significantly. 
Figure 1.1. Ratio of manufacturing imports to total expenditure volumes, Germany

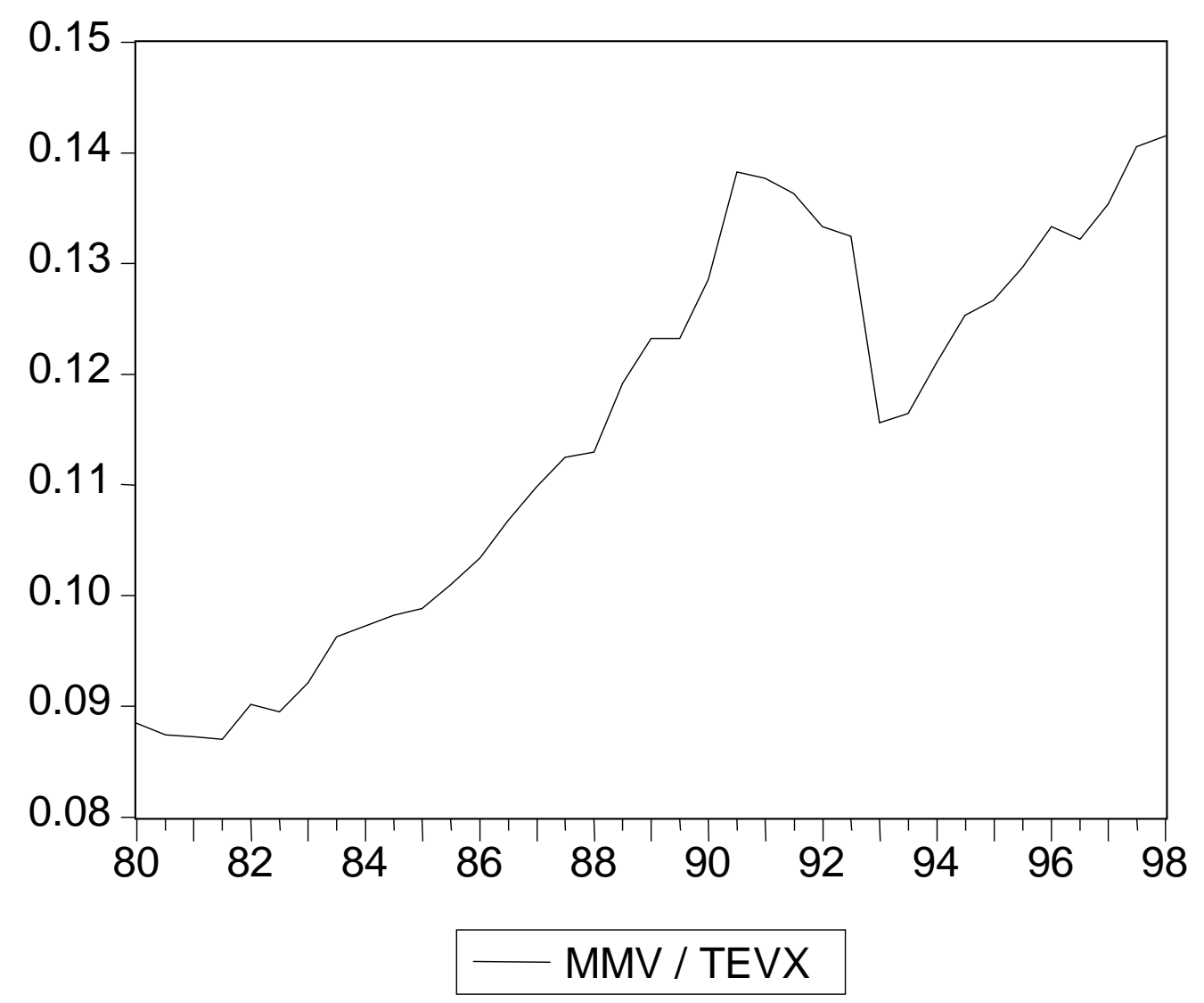


Table A.1 Estimation period of equation [1]

\begin{tabular}{ll}
\hline & Estimation period \\
\hline United States & $1964: \mathrm{S} 2-1999: \mathrm{S} 1$ \\
Japan & $1965: \mathrm{S} 1-1996: \mathrm{S} 2$ \\
Germany & $1969: \mathrm{S} 1-1998: \mathrm{S} 1$ \\
France & $1972: \mathrm{S} 1-1998: \mathrm{S} 2$ \\
Italy & $1964: \mathrm{S} 1-1997: \mathrm{S} 2$ \\
United Kingdom & $1972: \mathrm{S} 1-1996: \mathrm{S} 2$ \\
Canada & $1968: \mathrm{S} 2-1998: \mathrm{S} 2$ \\
Australia & $1970: \mathrm{S} 1-1999: \mathrm{S} 1$ \\
Austria & $1963: \mathrm{S} 1-1994: \mathrm{S} 2$ \\
Belgium & $1973: \mathrm{S} 1-1997: \mathrm{S} 2$ \\
Czech Republic & $1991: \mathrm{S} 1-1998: \mathrm{S} 2$ \\
Denmark & $1960: \mathrm{S} 2-1998: \mathrm{S} 2$ \\
Finland & $1975: \mathrm{S} 2-1997: \mathrm{S} 2$ \\
Greece & $1964: \mathrm{S} 1-1995: \mathrm{S} 2$ \\
Hungary & $1991: \mathrm{S} 1-1998: \mathrm{S} 2$ \\
Iceland & $1977: \mathrm{S} 1-1996: \mathrm{S} 2$ \\
Ireland & $1969: \mathrm{S} 1-1996: \mathrm{S} 2$ \\
Korea & $1984: \mathrm{S} 1-1998: \mathrm{S} 1$ \\
Mexico & $1971: \mathrm{S} 1-1999: \mathrm{S} 2$ \\
Netherlands & $1969: \mathrm{S} 2-1997: \mathrm{S} 2$ \\
New Zealand & $1970: \mathrm{S} 2-1997: \mathrm{S} 2$ \\
Norway & $1963: \mathrm{S} 2-1999: \mathrm{S} 1$ \\
Poland & $1991: \mathrm{S} 1-1998: \mathrm{S} 2$ \\
Portugal & $1973: \mathrm{S} 2-1995: \mathrm{S} 2$ \\
Spain & $1968: \mathrm{S} 2-1999: \mathrm{S} 1$ \\
Sweden & $1963: \mathrm{S} 2-1997: \mathrm{S} 2$ \\
Switzerland & $1972: \mathrm{S} 2-1995: \mathrm{S} 2$ \\
Turkey & $1970: \mathrm{S} 1-1996: \mathrm{S} 2$ \\
\hline
\end{tabular}


Table A.2 Detailed estimation results of equation [1], pooled coefficients ${ }^{1}$

ECO/WKP(2001)37

Dependent variable $\triangle \mathrm{InMMV}$

\begin{tabular}{|c|c|c|c|c|c|c|c|}
\hline & United States & Japan & Germany & France & Italy & United Kingdom & Canada \\
\hline Constant & $\begin{array}{l}-4.52 \\
(1.54)\end{array}$ & $\begin{array}{l}-4.25 \\
(0.42)\end{array}$ & $\begin{array}{l}-6.83 \\
(0.01)\end{array}$ & $\begin{array}{r}-12.32 \\
(0.93)\end{array}$ & $\begin{array}{r}-14.54 \\
(1.10)\end{array}$ & $\begin{array}{l}-1.73 \\
(0.45)\end{array}$ & $\begin{array}{l}-1.72 \\
(0.44)\end{array}$ \\
\hline$\Delta \mathrm{nMMV}_{\mathrm{t}-1}$ & $\begin{array}{l}-0.12 \\
(0.10)\end{array}$ & $\begin{array}{c}0.30 \\
(0.04)\end{array}$ & & & & & \\
\hline$\Delta \mathrm{nMMV}_{\mathrm{t}-2}$ & $\begin{array}{l}-0.24 \\
(0.05)\end{array}$ & $\begin{array}{l}-0.24 \\
(0.05)\end{array}$ & & & & & \\
\hline$\Delta \operatorname{lnTEV}_{\mathrm{t}}$ & $\begin{array}{c}2.57 \\
(0.15)\end{array}$ & $\begin{array}{c}1.70 \\
(0.08)\end{array}$ & $1.70^{2}$ & $\begin{array}{c}2.57 \\
(0.15)\end{array}$ & $\begin{array}{c}2.57 \\
(0.15)\end{array}$ & $\begin{array}{c}1.25 \\
(0.09)\end{array}$ & $\begin{array}{c}2.57 \\
(0.15)\end{array}$ \\
\hline$\Delta \operatorname{lnTEV} \mathrm{t}_{\mathrm{t}-1}$ & & & & & $\begin{array}{c}0.65 \\
(0.07)\end{array}$ & $\begin{array}{c}0.65 \\
(0.07)\end{array}$ & \\
\hline$\Delta \operatorname{lnTEV} \mathrm{t}_{\mathrm{t}-2}$ & & $\begin{array}{c}1.33 \\
(0.34)\end{array}$ & & & & $\begin{array}{c}0.36 \\
(0.29)\end{array}$ & \\
\hline \multicolumn{8}{|l|}{$\Delta \operatorname{lnTEV_{\mathrm {t}-3}}$} \\
\hline$\Delta \ln P_{t}$ & $\begin{array}{l}-0.36 \\
(0.05)\end{array}$ & $\begin{array}{l}-0.36 \\
(0.05)\end{array}$ & $-0.60^{2}$ & & $\begin{array}{l}-0.36 \\
(0.05)\end{array}$ & & $\begin{array}{l}-0.36 \\
(0.05)\end{array}$ \\
\hline$\Delta \ln P_{t-1}$ & $\begin{array}{l}-0.24 \\
(0.07)\end{array}$ & & & & & & \\
\hline Error correction coefficient & $\begin{array}{l}-0.12 \\
(0.03) \\
\end{array}$ & $\begin{array}{l}-0.23 \\
(0.02) \\
\end{array}$ & $-0.23^{2}$ & $\begin{array}{l}-0.43 \\
(0.03) \\
\end{array}$ & $\begin{array}{l}-0.43 \\
(0.03) \\
\end{array}$ & $\begin{array}{l}-0.12 \\
(0.03) \\
\end{array}$ & $\begin{array}{l}-0.12 \\
(0.03) \\
\end{array}$ \\
\hline Long-run demand elasticity & $\begin{array}{c}2.17 \\
(0.15)\end{array}$ & $\begin{array}{c}1.45 \\
(0.02)\end{array}$ & $2^{2}$ & $\begin{array}{c}1.89 \\
(0.04)\end{array}$ & $\begin{array}{c}1.89 \\
(0.04)\end{array}$ & $\begin{array}{c}1.45 \\
(0.02)\end{array}$ & $\begin{array}{c}1.45 \\
(0.02)\end{array}$ \\
\hline Long-run price elasticity & $\begin{array}{l}-0.84 \\
(0.05) \\
\end{array}$ & $\begin{array}{c}-1.18 \\
(0.05) \\
\end{array}$ & $-0.84^{2}$ & $\begin{array}{l}-0.45 \\
(0.07) \\
\end{array}$ & $\begin{array}{l}-0.45 \\
(0.07) \\
\end{array}$ & $\begin{array}{l}-0.45 \\
(0.07) \\
\end{array}$ & $\begin{array}{l}-1.18 \\
(0.05) \\
\end{array}$ \\
\hline R-squared & 0.82 & 0.74 & 0.85 & 0.85 & 0.79 & 0.76 & 0.76 \\
\hline Adjusted R-squared & 0.79 & 0.70 & 0.84 & 0.84 & 0.77 & 0.71 & 0.73 \\
\hline Standard error & 0.03 & 0.04 & 0.02 & 0.02 & 0.04 & 0.03 & 0.03 \\
\hline
\end{tabular}

1. Standard errors of coefficients in brackets

2. Imposed coefficients. 
ECO/WKP(2001)37

Table A.2 Detailed estimation results of equation [1], pooled coefficients (continued) ${ }^{1}$

Dependent variable $\Delta \mathrm{InMMV}$

\begin{tabular}{|c|c|c|c|c|c|c|c|c|}
\hline & Australia & Austria & Belgium & Denmark & Finland & Greece & Ireland & Iceland \\
\hline Constant & $\begin{array}{l}-6.20 \\
(0.49)\end{array}$ & $\begin{array}{l}-9.54 \\
(1.14)\end{array}$ & $\begin{array}{l}-6.38 \\
(0.51)\end{array}$ & $\begin{array}{l}-6.15 \\
(0.49)\end{array}$ & $\begin{array}{l}-6.09 \\
(0.48)\end{array}$ & $\begin{array}{l}-8.67 \\
(0.09)\end{array}$ & $\begin{array}{l}-2.25 \\
(0.005)\end{array}$ & $\begin{array}{c}-11.04 \\
(1.13)\end{array}$ \\
\hline$\Delta \mathrm{nMMV}_{\mathrm{t}-1}$ & $\begin{array}{c}0.30 \\
(0.04)\end{array}$ & & & & & & & \\
\hline$\Delta \mathrm{lnMMV}_{\mathrm{t}-2}$ & & $\begin{array}{c}0.21 \\
(0.10)\end{array}$ & & & & & & \\
\hline$\Delta \operatorname{lnMMV}_{\mathrm{t}-3}$ & & & & & $\begin{array}{c}0.16 \\
(0.07)\end{array}$ & & & \\
\hline$\Delta \operatorname{lnTEV} V_{t}$ & $\begin{array}{c}1.70 \\
(0.08)\end{array}$ & $\begin{array}{c}1.70 \\
(0.08)\end{array}$ & $\begin{array}{c}1.70 \\
(0.08)\end{array}$ & $\begin{array}{c}1.70 \\
(0.08)\end{array}$ & $\begin{array}{c}1.70 \\
(0.08)\end{array}$ & $\begin{array}{c}0.17 \\
(0.27)\end{array}$ & $1.25^{2}$ & $\begin{array}{c}1.70 \\
(0.08)\end{array}$ \\
\hline$\Delta \operatorname{lnTEV_{t-1}}$ & & $\begin{array}{c}0.65 \\
(0.07)\end{array}$ & & & & $1.21^{2}$ & & \\
\hline \multicolumn{9}{|l|}{$\Delta \operatorname{lnTEV}_{\mathrm{t}-2}$} \\
\hline$\Delta \operatorname{lnTEV} V_{t-3}$ & & & $\begin{array}{c}0.09 \\
(0.30)\end{array}$ & & & & & \\
\hline$\Delta \ln P_{t}$ & $\begin{array}{l}-1.01 \\
(0.09)\end{array}$ & $\begin{array}{l}-0.60 \\
(0.05)\end{array}$ & & $\begin{array}{l}-0.36 \\
(0.05)\end{array}$ & $\begin{array}{l}-0.60 \\
(0.05)\end{array}$ & $\begin{array}{l}-0.60 \\
(0.05)\end{array}$ & $-0.36^{2}$ & $\begin{array}{l}-1.01 \\
(0.09)\end{array}$ \\
\hline$\Delta \operatorname{lnP}_{\mathrm{t}-1}$ & & & & & & & & $-0.24^{2}$ \\
\hline Error correction coefficient & $\begin{array}{l}-0.43 \\
(0.03)\end{array}$ & $\begin{array}{l}-0.66 \\
(0.07)\end{array}$ & $\begin{array}{l}-0.43 \\
(0.03)\end{array}$ & $\begin{array}{l}-0.43 \\
(0.03)\end{array}$ & $\begin{array}{l}-0.43 \\
(0.03)\end{array}$ & $\begin{array}{l}-0.66 \\
(0.07)\end{array}$ & $-0.23^{2}$ & $\begin{array}{l}-0.78 \\
(0.08)\end{array}$ \\
\hline Long-run demand elasticity & $\begin{array}{c}1.45 \\
(0.02)\end{array}$ & $\begin{array}{c}1.45 \\
(0.02)\end{array}$ & $\begin{array}{c}1.45 \\
(0.02)\end{array}$ & $\begin{array}{c}1.45 \\
(0.02)\end{array}$ & $\begin{array}{c}1.45 \\
(0.02)\end{array}$ & $\begin{array}{c}1.36 \\
(0.05)\end{array}$ & $1.36^{2}$ & $\begin{array}{c}1.45 \\
(0.02)\end{array}$ \\
\hline Long-run price elasticity & $\begin{array}{l}-1.18 \\
(0.05)\end{array}$ & $\begin{array}{l}-0.84 \\
(0.05)\end{array}$ & $\begin{array}{l}-0.37 \\
(0.04)\end{array}$ & $\begin{array}{l}-0.37 \\
(0.04)\end{array}$ & $\begin{array}{l}-0.37 \\
(0.04)\end{array}$ & $\begin{array}{l}-1.18 \\
(0.05)\end{array}$ & $-0.10^{2}$ & $\begin{array}{l}-0.84 \\
(0.05)\end{array}$ \\
\hline R-squared & 0.66 & 0.72 & 0.69 & 0.67 & 0.78 & 0.55 & 0.65 & 0.78 \\
\hline Adjusted R-squared & 0.61 & 0.68 & 0.63 & 0.65 & 0.73 & 0.52 & 0.63 & 0.77 \\
\hline Standard error & 0.05 & 0.03 & 0.03 & 0.03 & 0.04 & 0.06 & 0.03 & 0.06 \\
\hline
\end{tabular}

1. Standard errors of coefficients in brackets.

2. Imposed coefficients. 
ECO/WKP(2001)37

Table A.2 Detailed estimation results of equation [1], pooled coefficients (continued) ${ }^{1}$ Dependent variable $\Delta \mathrm{InMMV}_{\mathrm{t}}$

\begin{tabular}{|c|c|c|c|c|c|c|c|c|c|}
\hline & Korea & Netherlands & Norway & New Zealand & Portugal & Spain $^{3}$ & Sweden & Switzerland & Turkey \\
\hline Constant & $\begin{array}{l}-8.53 \\
(1.67)\end{array}$ & $\begin{array}{l}-5.90 \\
(0.22)\end{array}$ & $\begin{array}{l}-5.08 \\
(0.76)\end{array}$ & $\begin{array}{l}-8.86 \\
(1.05)\end{array}$ & $\begin{array}{c}-12.32 \\
(0.93)\end{array}$ & $\begin{array}{l}-6.37 \\
(2.57)\end{array}$ & $\begin{array}{l}-3.29 \\
(0.32)\end{array}$ & $\begin{array}{l}-3.10 \\
(0.30)\end{array}$ & $\begin{array}{l}-3.22 \\
(0.32)\end{array}$ \\
\hline$\Delta \mathrm{InMMV}_{\mathrm{t}-1}$ & & & & & & & & $\begin{array}{c}0.30 \\
(0.04)\end{array}$ & \\
\hline \multicolumn{10}{|l|}{$\Delta \mathrm{lnMMV}_{\mathrm{t}-2}$} \\
\hline \multicolumn{10}{|l|}{$\Delta \mathrm{InMMV}_{\mathrm{t}-3}$} \\
\hline$\Delta \operatorname{lnTEV} V_{t}$ & $1.70^{2}$ & $1.25^{2}$ & & $\begin{array}{c}1.70 \\
(0.08)\end{array}$ & $\begin{array}{c}1.25 \\
(0.09)\end{array}$ & $\begin{array}{c}2.24 \\
(0.65)\end{array}$ & $\begin{array}{c}1.70 \\
(0.08)\end{array}$ & $\begin{array}{c}1.25 \\
(0.09)\end{array}$ & $\begin{array}{c}1.25 \\
(0.09)\end{array}$ \\
\hline$\Delta \operatorname{lnTEV_{t-1}}$ & & & $\begin{array}{c}0.65 \\
(0.07)\end{array}$ & $\begin{array}{c}0.65 \\
(0.07)\end{array}$ & $\begin{array}{c}1.75 \\
(0.22)\end{array}$ & & & & $\begin{array}{c}0.65 \\
(0.07)\end{array}$ \\
\hline \multicolumn{10}{|l|}{$\Delta \operatorname{lnTEV} \mathrm{t}_{\mathrm{t}-2}$} \\
\hline \multicolumn{10}{|l|}{$\Delta \operatorname{lnTEV} \mathrm{t}_{\mathrm{t}-3}$} \\
\hline$\Delta \ln P_{t}$ & $-0.36^{2}$ & & & & $\begin{array}{l}-0.36 \\
(0.05)\end{array}$ & $\begin{array}{l}-0.68 \\
(0.14)\end{array}$ & $\begin{array}{l}-0.60 \\
(0.05)\end{array}$ & $\begin{array}{l}-0.60 \\
(0.05)\end{array}$ & $\begin{array}{l}-0.60 \\
(0.05)\end{array}$ \\
\hline$\Delta \ln P_{t-1}$ & & & & & $\begin{array}{l}-0.24 \\
(0.07)\end{array}$ & & & & \\
\hline Error correction coefficient & $\begin{array}{l}-0.91 \\
(0.16)\end{array}$ & $-0.43^{2}$ & $\begin{array}{l}-0.43 \\
(0.03)\end{array}$ & $\begin{array}{l}-0.66 \\
(0.07)\end{array}$ & $\begin{array}{l}-0.43 \\
(0.03)\end{array}$ & $\begin{array}{l}-0.16 \\
(0.04)\end{array}$ & $\begin{array}{l}-0.23 \\
(0.02)\end{array}$ & $\begin{array}{l}-0.23 \\
(0.02)\end{array}$ & $\begin{array}{l}-0.23 \\
(0.02)\end{array}$ \\
\hline Long-run demand elasticity & $\begin{array}{c}1.22 \\
(0.02)\end{array}$ & $\begin{array}{c}1.45 \\
(0.02)\end{array}$ & $\begin{array}{c}1.36 \\
(0.05)\end{array}$ & $\begin{array}{c}1.45 \\
(0.02)\end{array}$ & $\begin{array}{c}1.89 \\
(0.04)\end{array}$ & $\begin{array}{c}2.16 \\
(0.34)\end{array}$ & $\begin{array}{c}1.45 \\
(0.02)\end{array}$ & $\begin{array}{c}1.45 \\
(0.02)\end{array}$ & $\begin{array}{c}1.45 \\
(0.02)\end{array}$ \\
\hline Long-run price elasticity & $-0.37^{2}$ & $-0.37^{2}$ & $\begin{array}{l}-0.45 \\
(0.07)\end{array}$ & $\begin{array}{l}-0.37 \\
(0.04)\end{array}$ & $\begin{array}{l}-0.45 \\
(0.07)\end{array}$ & $\begin{array}{l}-0.96 \\
(0.51)\end{array}$ & $\begin{array}{l}-1.18 \\
(0.05)\end{array}$ & $\begin{array}{l}-1.18 \\
(0.05)\end{array}$ & $\begin{array}{l}-0.37 \\
(0.04)\end{array}$ \\
\hline R-squared & 0.85 & 0.65 & 0.39 & 0.76 & 0.83 & 0.80 & 0.81 & 0.69 & 0.70 \\
\hline Adjusted R-squared & 0.83 & 0.63 & 0.32 & 0.73 & 0.79 & 0.77 & 0.77 & 0.65 & 0.66 \\
\hline Standard error & 0.04 & 0.02 & 0.04 & 0.05 & 0.04 & 0.03 & 0.03 & 0.02 & 0.08 \\
\hline
\end{tabular}

1. Standard errors of coefficients in brackets.

2. Imposed coefficients.

3. TEV defined as total expenditures minus private non-residential investment. 
ECO/WKP(2001)37

\section{Table A.3 Dummies in the estimation ${ }^{1}$}

The following dummies were used in the estimation to correct for outliers or shifting trends:

\begin{tabular}{ll} 
United States & 1975,1984 \\
Japan & 1973 \\
Germany & $1972,1973,1993:$ S1, plus a shift dummy from 1968:S2 to 1990:S2 \\
France & 1977 \\
United Kingdom & $1980:$ S2, 1981:S2 \\
Canada & 1970 \\
& $1974:$ S2 \\
Australia & 1993 \\
Austria & $1985,1986,1987$ \\
Belgium & $1988: S 1,1988: S 2$ \\
Finland & $1989: S 2,1990: S 1$, plus one shift dummy from 1978:S1 to 1987:S2 \\
Greece & $1971: S 2,1975: S 1,1982: S 2$ \\
Ireland & $1992: S 2,1993: S 1,1993: S 2$ \\
Korea & $1976: S 2,1977,1982: S 2$ \\
Mexico & 1970, plus one shift dummy from 1984:S1 to 1992:S2 \\
Netherlands & 1988 \\
New Zealand & 1988, plus one shift dummy from 1969:S1 to 1975:S2, and one shift dummy from \\
Norway & $1981: S 1$ to 1987:S2 \\
Portugal & $1993: S 1$ \\
Spain & $1971: S 1,1978$ \\
Sweden & $1966,1974,1978: S 2,1991,1992$ \\
Turkey & 1978 \\
\hline
\end{tabular}

1. S1 means first semester; S2 second semester. 


\section{ECONOMICS DEPARTMENT \\ WORKING PAPERS}

310. Trade Linkages and the Trade Matrices in the OECD Interlink Model (October 2001) Laurence Le Fouler, Wim Suyker and Dave Turner

309. Encouraging Environmentally Sustainable Growth in Australia (October 2001) Ann Vourc'h and Robert Price

308. Financial Market Liberalisation, Wealth and Consumption (September 2001) Laurence Boone, Nathalie Girouard and Isabelle Wanner

307. The Economic Integration of Germany's New Länder (September 2001) Eckhard Wurzel

306. Standard Shocks in the OECD Interlink Model (September 2001) Thomas Dalsgaard, Christophe André and Pete Richardson

305. Fiscal Implications of Ageing: Projections of Age-related Spending (September 2001) Thai Thanh Dang, Pablo Antolin and Howard Oxley

304. The Width of the Intra-European Economic Borders (August 2001) Alain de Serres, Peter Hoeller and Christine de la Maisonneuve

303. Surveillance of Tax Policies: A Synthesis of Findings in Economic Surveys (July 2001) Paul van den Noord and Christopher Heady

302. Reforming the Tax System in Portugal (July 2001) Chiara Bronchi, José C. Gomes-Santos

301. Tax Systems in European Union Countries (June 2001) Isabelle Joumard

300. Encouraging Environmentally Sustainable Growth in Belgium (June 2001) Paul O’Brien, David Carey, Jens Høj, Andreas Woergoetter

299. Encouraging Environmentally Sustainable Growth in Poland (June 2001) Grzegorz Peszko, Patrick Lenain

298. Tracking the Euro (June 2001) Vincent Koen, Laurence Boone, Alain de Serres, Nicola Fuchs

297. Firm Dynamics and Productivity Growth: A Review of Micro-evidence from OECD Countries (June 2001) Sanghoon Ahn

296. How should Norway Respond to Ageing? (May 2001) Pablo Antolín and Wim Suyker

295. How will Ageing Affect Finland? (May 2001) Pablo Antolín, Howard Oxley and Wim Suyker

294. Sectoral Regulatory Reforms in Italy: Framework and Implications (May 2001) Alessandro Goglio 


\section{ECO/WKP(2001)37}

293. Encouraging Environmentally Sustainable Growth: Experience in OECD Countries (May 2001) Paul O’Brien and Ann Vourc'h

292. Increasing Simplicity, Neutrality and Sustainability: A Basis for Tax Reform in Iceland (May 2001) Richard Herd and Thorsteinn Thorgeirsson

291. Options for Reforming the Tax System in Greece (April 2001) Chiara Bronchi

290. Encouraging Environmentally Sustainable Growth in Canada (March 2001) Ann Vourc'h

289. Encouraging Environmentally Sustainable Growth in Sweden (March 2001) Deborah Roseveare

288. Public Spending in Mexico: How to Enhance its Effectiveness (March 2001) Bénédicte Larre and Marcos Bonturi

287. Regulation in Services: OECD Patterns and Economic Implications (February 2001) Giuseppe Nicoletti

286. A Small Global Forecasting Model (February 2001) David Rae and David Turner

285. Managing Public Expenditure: Some Emerging Policy Issues and a Framework for Analysis (February 2001) Paul Atkinson and Paul van den Noord

284. Trends in Immigration and Economic Consequences (February 2001) Jonathan Coppel, Jean-Christophe Dumont and Ignazio Visco

283. Economic Growth: The Role of Policies and Institutions.

Panel Data Evidence from OECD Countries

(January 2001) Andrea Bassanini, Stefano Scarpetta and Philip Hemmings

282. Does Human Capital Matter for Growth in OECD Countries? Evidence from Pooled Mean-Group Estimates (January 2001) Andrea Bassanini and Stefano Scarpetta

281. The Tax System in New Zealand: An Appraisal and Options for Change (January 2001) Thomas Dalsgaard

280. Contributions of Financial Systems to Growth in OECD Countries (January 2001) Michael Leahy, Sebastian Schich, Gert Wehinger, Florian Pelgrin and Thorsteinn Thorgeirsson

279. House Prices and Economic Activity

(January 2001) Nathalie Girouard and Sveinbjörn Blöndal

278. Encouraging Environmentally Sustainable Growth in the United States (January 2001) Paul O’Brien

277. Encouraging Environmentally Sustainable Growth in Denmark (January 2001) Paul O’Brien and Jens Høj

276. Making Growth more Environmentally Sustainable in Germany (January 2001) Grant Kirkpatrick, Gernot Klepper and Robert Price 